Türk Turizm Araştırmaları Dergisi
2021,5(2): $925-945$.
ISSN: $2587-0890$ Dergi web sayfasi: $\underline{\text { https://www.tutad.org }}$

\title{
Üniversite Öğrencilerinin Destinasyon İmajı Algısı Üzerinde Sosyal Medyanın Etkisi: Lavanta Turizmi Örneği*
}

Büşra AŞIROĞLU, Doktora Öğrencisi, Süleyman Demirel Üniversitesi, Sosyal Bilimler Enstitüsü, Isparta, e-posta: asiroglubusra@gmail.com ORCID: https://orcid.org/0000-0002-9928-0940

Doç. Dr. Murat ÇUHADAR, Süleyman Demirel Üniversitesi, İktisadi ve İdari Bilimler Fakültesi, Isparta, e-posta: muratcuhadar@sdu.edu.tr ORCID: https://orcid.org/0000-0003-0434-1550

\section{Öz}

Günümüzde web tabanlı dijital teknolojilerin gelişmesi ve kullanıcı sayılarının artmasıyla birlikte, bireylerin çeşitli turistik bölge, şehir, kasaba-köy ve işletmelerde yaşadıkları seyahat deneyimlerini paylaşabilmesine olanak tanıyan sosyal medya platformları popüler konuma ulaşmıştır. Bireyler tatil ve seyahat öncesinde çoğunlukla internet ortamında bilgi arama davranışı içerisinde olurken, seyahat esnasında ve seyahat sonrasında ise çoğunlukla tatil-seyahat deneyimlerini Facebook, Twitter ve Instagram gibi sosyal medya mecralarında ve Tripadvisor gibi turizm ve seyahat portallarında paylaşma eğiliminde olmaktadır. Yapılan paylaşımlarla insanların zihninde seyahat edilen bölgeyle ilgili olumlu ya da olumsuz bir izlenim oluşmaktadır. Olumlu izlenimler sonucu söz konusu destinasyona olan ilgi artmakta ve seyahatler gerçekleştirilmektedir. Bu çalışmada, destinasyon imajı algısı üzerinde sosyal medyanın etkisi araştırılmaktadır. Uygulama alanı olarak, son yıllarda bilhassa sosyal medyada yapılan paylaşımlar sayesinde popüler hale gelen Isparta ili sınırları içerindeki Kuyucak Lavanta bahçeleri seçilmiştir. Çalışma kapsamında Süleyman Demirel Üniversitesinin farklı akademik birimlerinde ön lisans, lisans ve lisansüstü düzeylerinde öğrenim gören ve Kuyucak Lavanta bahçelerini ziyaret etmiş 32 öğrenci ile yarı yapılandırılmış görüşme gerçekleştirilmiştir. Çalışma neticesinde, üniversite öğrencilerinin Isparta ili Keçiborlu ilçesine bağlı Kuyucak Köyü'nde bulunan lavanta turizmi merkezleri ziyaretleri öncesi ve sonrasında bu bölgeyle ilgili algıları analiz edilerek etkileri ortaya konulmuştur. Ayrıca çalışmada söz konusu destinasyonun tanınırlığının sağlanmasında sosyal medya mecralarının ne kadar etkili olduğu ve bu etkinin artırılması için neler yapılabileceği sorularına da yanıt aranmaktadır. Araştırma bulgularına göre lavanta bahçelerinin bulunduğu bölge, katılımcılar nezdinde genel olarak olumlu bir izlenime sahiptir. Bu izlenimin oluşmasında ve bölgenin gözde seyahat rotalarından biri haline gelmesinde ise, sosyal medya mecralarının önemli payının olduğu tespit edilmiştir.

\footnotetext{
* Bu çalışma, Süleyman Demirel Üniversitesi, Sosyal Bilimler Enstitüsü, Turizm İşletmeciliği Anabilim dalında gerçekleştirilen “Üniversite Öğrencilerinin Destinasyon İmajı Algısı Üzerinde Sosyal Medyanın Etkisi: Lavanta Turizmi Örneği" adlı yüksek lisans tezinden derlenmiştir.
}

Anahtar Kelimeler: Sosyal Medya, Destinasyon İmajı, Lavanta Turizmi, Lavanta Kokulu Köy.

Makale Gönderme Tarihi: 28.12.2020

Makale Kabul Tarihi: 01.06.2021

\section{Önerilen Atıf:}

Aşıroğlu, B. ve Çuhadar, M. (2021). Üniversite Öğrencilerinin Destinasyon İmajı Algısı Üzerinde Sosyal Medyanın Etkisi: Lavanta Turizmi Örneği, Türk Turizm Araştırmaları Dergisi, 5(2): 925-945.

(c) 2021 Türk Turizm Araştırmaları Dergisi. 


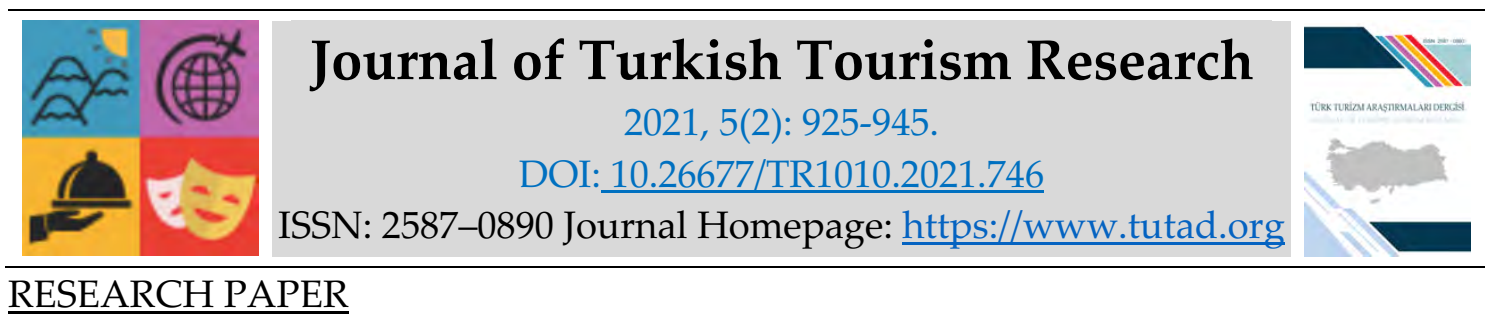

\title{
The Effect of Social Media on Destination Image Perception of University Students: The Case of Lavender Tourism
}

Büşra AŞIROĞLU, Ph.D Student, Süleyman Demirel University, Social Sciences Institute, Isparta, e-mail: asiroglubusra@gmail.com ORCID: https://orcid.org/0000-0002-9928-0940

Associate Prof. Dr. Murat ÇUHADAR, Süleyman Demirel University, Faculty of Economics and Administrative Sciences, Isparta, e-mail: muratcuhadar@sdu.edu.tr ORCID: https://orcid.org/0000-0003-0434-1550

\begin{abstract}
Today, with the development of web-based digital technologies and the increase in the number of users, social media platforms that allow individuals to share their travel experiences in various touristic regions, cities, towns-villages and businesses have reached a popular position. While individuals are mostly in the behavior of searching for information on the internet before vacation and travel, they tend to share their holiday-travel experiences on social media such as Facebook, Twitter and Instagram and tourism and travel portals such as Tripadvisor during and after travel. With the posts made, a positive or negative impression is formed in the minds of the people about the traveled region. As a result of positive impressions, interest in the destination in question increases and travels are made. In this study, the effect of social media on the destination image perception is investigated. The lavender gardens of Kuyucak within the borders of Isparta province, which have become popular in recent years, especially thanks to the posts on social media, have been chosen as the field of application. Within the scope of the study, semi-structured interviews were conducted with 32 students who studied at associate, undergraduate and graduate levels in different academic units of Süleyman Demirel University and visited Kuyucak Lavender gardens. As a result of the study, before and after the visits of university students to lavender fields in Kuyucak Village of Keçiborlu district of Isparta province, their perceptions about this region were analyzed and its effects were revealed. In addition, the study also sought answers to the questions of how effective social media channels are in ensuring the recognition of the destination in question and what can be done to increase this effect. According to the research findings, the region where lavender gardens are located has a generally positive impression on the participants. It has been determined that social media channels have an important role in forming this impression and making it one of the favorite travel routes of the region.
\end{abstract}

Keywords: Social Media, Destination Image, Lavender Tourism, “Lavanta Kokulu Köy”.

Received: 28.12 .2020

Accepted: 01.06.2021

Suggested Citation:

Aşıroğlu, B. and Çuhadar, M. (2021). The Effect of Social Media on Destination Image Perception of University Students: The Case of Lavender Tourism, Journal of Turkish Tourism Research, 5(2): 925-945.

(C) 2021 Türk Turizm Araştırmaları Dergisi. 


\section{Gíriş}

Son yıllarda bilgi ve iletişim teknolojilerinde meydana gelen ilerlemeler sayesinde, turizm destinasyonlarının tanıtımı ve pazarlanması çoğu zaman ek bir maliyet gerektirmeden web tabanlı dijital mecralar ile gerçekleştirilebilmektedir. Turistler seyahat kararı almadan önce internet üzerinden destinasyon yönelik detaylı araştırmalar yapabilmektedir. Seyahat sırasında dijital teknolojiler sayesinde kaliteli hizmet alabilmekte, seyahat sonrasında ise deneyimleriyle ilgili görüş ve düşüncelerini diğer internet kullanıcılarıyla paylaşabilmektedirler. Yapılan paylaşımlar hem paylaşım yapan turistin seyahat ettiği destinasyonla ilgili izlenimlerini ortaya koymakta hem de potansiyel turistlerin bu destinasyonla ilgili izlenimlerinin olumlu ya da olumsuz yönde şekillenmesini sağlamaktadır. Bu neticede internet ve sosyal medyanın seyahat kararını ve seyahat edilecek destinasyonun imaj oluşumunu etkilediği söylenebilir.

İnsanların bir destinasyon ile ilgili zihinlerinde oluşan algı, izlenim şeklinde ifade edilebilecek bir kavram olan destinasyon imajı, turizm sektörü için rekabet unsuru niteliğindedir. Sektör çalışanları bu noktada üstünlük sağlayabilmek, destinasyonlara çok sayıda turist çekebilmek için olumlu bir imaj edinme konusunda çaba sarf etmektedir. Teknoloji ve imaj arasındaki güçlü ilişkinin bilincinde olan kesimler, dinamik ve etkili imaj oluşturma konusundaki çabalarına interneti ve sosyal medya platformlarını dâhil etmektedirler. Özellikle daha çok görsel içeriklerin paylaşılması için tasarlanan uygulamaların turizm destinasyonlarının tanıtımı konusunda önemli araçlar olduğunu söylemek mümkündür. Bu paylaşımlarla birlikte bir turizm destinasyonunun küresel çapta tanınması ve ilgi çekici hale getirilmesi sağlanabilmektedir. Sosyal medya platformlarında yapılan paylaşımlar neticesinde yerli ve yabancı turistlerin ilgi odağı olan turizm destinasyonlarından biri Isparta'nın Keçiborlu İlçesi'nde bulunan Kuyucak Köyü'dür. Köyün içerisinde bulunan lavanta bahçelerini ziyaret eden turistler, ziyaret deneyimlerini sosyal medya aracılığıyla paylaşarak bölgenin kısa sürede geniş kitlelerce tanınmasına olanak sağlamıştır. Lavanta Kokulu Köy projesinin hayata geçirilmesi, köyün bu isimle tanıtılması ve bu tanıtımlar için daha çok sosyal medyanın kullanılması gibi faaliyetler bölge imajinın geliştirilmesi hususunda aktif rol oynamıştır.

Son yıllarda gözde turizm merkezlerinden biri haline gelen köye akademik çalışmalarda da yer verilmeye başlanmıştır. Bu çalışmanın kaleme alınarak gerçekleştirilmesinde, literatürde lavanta turizmi destinasyonlarını ziyaret eden ziyaretçilerin algılarının irdelendiği çalışmaların sınırlı sayıda olması etkili olmuştur. Lavantanın Isparta ili için bir imaj unsuru haline gelmesi, bölgenin özellikle son yıllarda sosyal medya mecralarının etkisiyle popülerleşmesi, ulusal ve uluslararası düzeyde tanınıyor olan bu bölgede turizm faaliyetlerinin aktif bir biçimde gerçekleştiriliyor olması gibi sebepler dolayısıyla çalışma alanı Kuyucak Köyü olarak belirlenmiştir. Turistlerin bu destinasyonla ilgili sahip oldukları izlenimin ve bu izlenimin oluşmasında etkili olan araçların anlaşılması hem ilgili bölgenin hem de Isparta ili turizminin geliştirilmesi konusunda etkili olacaktır. Örneklemi üniversite öğrencileri olarak belirlenen bu araştırmanın amacı, destinasyon imajı algısı üzerinde sosyal medyanın etkisinin ölçülmesidir. Katılımcıların sadece üniversite öğrencilerinden oluşması araştırmanın sınırlılığını olarak kabul edilebilir. Çalışmada sosyal medya ve destinasyon imajı kavramlarına değinilerek bu iki kavram arasındaki ilişki irdelenmiştir. Son olarak araştırma amacı doğrultusunda yapılan analizlere ve elde edilen bulgulara yer verilmiştir. Benzer konudaki çalışmaların sınırlı olması nedeniyle literatüre ve konuyla ilgili ileriye yönelik yapılacak çalışmalara katkı sağlayacağı öngörülen bu araştırmanın lavanta turizmi kapsamında faaliyet gösteren sektör çalışanlarının ve kurumların ileriye dönük planlamalarında da yol gösterici bir rol oynayacağı düşünülmektedir. 


\section{LİTERATÜR ÖZETİ}

\section{Sosyal Medya}

İnsanlar doğası gereği sorgulayan, duygu ve düşüncelerini paylaşma ve diğer insanlarla iletişim halinde olma ihtiyacı hisseden sosyal varlıklardır. Bu ihtiyaçlarını aile, akraba, arkadaş ortamı gibi yakın çevresiyle karşılayan insanlar, gelişen internet teknolojisiyle birlikte söz konusu etkileşimi yakın çevresi dışındaki bireylerle de sağlama imkânına sahip olmuşlardır. İnsanların internet üzerinden diğer insanlarla iletişim kurarak sosyalleşmesini ifade eden sosyal terimi ile sağlanan iletişimin radyo, televizyon, bilgisayar, telefon gibi araçlarla gerçekleştirilmesini ifade eden medya terimi birleştirilmiş ve sosyal medya kavramı ortaya çıkmıştır (Safko, 2010: 4). Bu kavram insanların gündelik hayatın stresinden uzaklaşarak, boş zamanlarını değerlendirdiği, araştırma yapma, bilgi edinme, iletişim kurma, eğlenme gibi birçok aktiviteyi gerçekleştirdiği bir teknoloji olarak ifade edilmektedir (Hazar, 2011: 153-154). Sosyal medyanın bugünkü konumuna ulaşmasındaki en büyük etkenin internetin ortaya çıkması olduğu bilinmektedir. İnternetin günlük hayatta kullanılmasıyla ilk olarak Web 1.0 dönemi başlamıştır. Web 1.0 kavramı, kullanıcıların internet üzerinden web sayfalarındaki bilgiye ulaşabildiği, sayfanın içeriğiyle herhangi bir etkileşime giremediği (yorum, paylaşım yapma vs.) salt okunur web teknolojisi olarak ifade edilmektedir (Nath vd., 2014: 86). Bu teknolojinin temel amacı, internet üzerinden az sayıda yazarın çok sayıda okuyucu kitlesine ulaşmasını sağlamaktır (Naik ve Shivalingaiah, 2008: 500). Fakat az sayıda içerik üretici, çok sayıda içerik okuyucunun bulunması, kullanıcıların diğer kullanıcılarla etkileşim sağlayamıyor olması, Web 1.0'ın bir yazılım hizmeti değil, bir uygulama olarak görülüyor olması yeni teknoloji arayışlarına zemin hazırlamıştır (Nath vd., 2014: 86). Böylece "okuma-yazma ağı" olarak ifade edilen kullanıcıların içerik okumalarının yanı sıra bu içeriklerle ilgili paylaşım ve yorum yapabilmelerine olanak sağlayan Web 2.0 dönemi başlamıştır (Murugesan, 2007: 34). Etkileşimli internet teknolojileri sayesinde ortaya çıkan, en önemli özelliği kullanıcı odaklı içerik yaratılması olan sosyal medya, Twitter, Instagram, Facebook, Youtube, Whatsapp gibi birçok platformu kapsamaktadır.

\section{Destinasyon İmaj1}

İnsanlar seyahat ettikleri bölgelerle ilgili deneyimleri doğrultusunda çeşitli izlenimlere sahip olmakta, bu izlenimler insanların o bölgeyi tekrar ziyaret etmeleri ve bu bölgeyle ilgili deneyimlerini diğer insanlarla paylaşmaları sürecinde etkili olmaktadır. Bu noktada destinasyon imajı olgusu ön plana çıkmaktadır. Destinasyon imajı, bir bölgenin bilinirliğini ve sürdürülebilirliğini sağlaması açısından etkili bir unsurdur (Font, 1997: 23). Destinasyon imajı kavramının anlaşılması, turizm olgusu için son derece önem arz etmektedir. Bu kavram ise destinasyon ve imaj terimlerine açıklık getirildiğinde daha iyi anlaşılabilmektedir. Destinasyon, doğal, tarihi, sosyo-kültürel vb. çekicilikleri kapsayan, festival, karnaval gibi çeşitli etkinliklerle zenginleştirilebilen, turizm altyapısı ve kapasitesine sahip coğrafi bölge şeklinde ifade edilmektedir (Tosun ve Jenkins, 1996; Sarı ve Kozak, 2005: 254). Akademik yazında destinasyon kavramina alternatif olarak "turizm alani", "turizm merkezi", "turizm bölgesi", "turizm mahalli" gibi ifadelerin kullanıldığ görülmektedir (Atay, 2003: 27). Turistlerin, turizm faaliyetlerini gerçekleştirmek üzere gidecekleri yeri belirlemelerinde en önemli etken bölgenin sahip olduğu imajdır. Turizm kapsamında sunulan hizmetler önceden temin edilemeyen, soyut hizmetler olduğu için seyahat edilen bölgelerin birbirleriyle olan rekabetleri imaj vasitasiyla gerçekleşmektedir (Özaltaş Serçek ve Serçek, 2017: 7). Diğer bir ifadeyle, turistlerin bir yerle ilgili zihinlerinde oluşan imaj, söz konusu destinasyonu tercih etmelerinde önemli bir yere sahiptir. Latince "imago" olarak ifade edilen ve Türkçe karşıllğ̆ "resim" olan imaj kavramı; bir kişi, ürün, hizmet, olay, işletme vb. ile ilgili, insanların zihninde oluşan algı, görüntü, resim biçiminde 
tanımlanabilmektedir (Ker, 1998: 7). Bu tanımlamalardan yola çıkılarak destinasyon imajını, insanların bir ülke, şehir ya da bölge ile ilgili zihinlerinde canlandırdıkları izlenim olarak özetlemek mümkündür. Turizm literatüründe destinasyon imajı ile ilgili çalışmalar Edward Mayo, Clare Gunn gibi yazarların öncülügüünde 1970'li yıllarda başlamaktadır (Pike, 2002: 541). Turistlerin turizm faaliyetlerini icra etmek üzere gidecekleri bölgeyle ilgili sahip oldukları imaj, söz konusu destinasyonun geleceğini belirlemesi açısından hayati bir öneme sahiptir.

\section{Sosyal Medya ve Destinasyon İmajı Arasındaki İlişki}

Teknoloji çağıyla birlikte, potansiyel turistlerin bir bölgeyle ilgili bilgi sahibi olabilmek için seyahat acenteleri, tur operatörleri ve çeşitli turizm işletmeleriyle iletişim kurarak başvurdukları geleneksel yolların yerini dijital mecra almıştır (Dina ve Sabou, 2012: 27). Özellikle milyonlarca kullanıcıya sahip olan sosyal medya araçları destinasyon tanıtımı için oldukça etkilidir. Sosyal medya ve içerisinde barındırdığı platformlar, destinasyonlar ve insanlar arasındaki etkileşimin gerçekleştiği en popüler araçlar olarak bilinmektedir (Munar ve Jacopsen, 2013'ten akt. Ünal, 2019: 2). Web tabanlı dijital platformlar üzerinden paylaşllan her bilgi bir imaj unsuru konumundadır. İnsanlar yalnızca imajı algılayan değil destinasyonla ilgili bireysel fikirlerini paylaşarak imajı yaratan rolü de üstlenmektedir (Dwivedi, 2009: 226). Turistler fikirlerini görsellerle desteklediklerinde imaj üzerindeki etki daha da artmaktadır.

Dijital çağda pek çok turist fotoğraflarını coğrafi etiketlerle çevrimiçi platformlarda paylaşma alışkanlığını benimsemiştir. Fotoğrafların algılanan imajın inşasındaki ana etkenlerden biri olduğu düşünüldüğünde, gidilen yerin fotoğrafının çekilip çeşitli platformlarda paylaşılması ve beğenilmesiyle o bölgenin değerinin önemli ölçüde arttığı söylenebilmektedir (Donaire vd., 2014: 26). Çekilen fotoğrafların doğal ve gerçekçi biçimde paylaşılması fotoğraflanabilir çekiciliğe sahip olan destinasyonlar ile ilgili oluşan olumlu imajın devamlılığının sağlanması açısından göz önünde bulundurulması gereken bir husustur (Ongun ve Erbaş, 2020). Görsel çekicilikler soyut olan turistik ürünün somutlaşmasına olanak sağlamakta ve turistlerin seyahat motivasyonlarını etkilemektedir. 11 Mart 2011 tarihinde meydana gelen deprem sonrası Japonya'nın tutumu bu etkiye açıklık getirecek örneklerden biridir. Gerçekleşen afet sonrasında Japonya, insanların zihninde enkaz altında kalmış, tahribata uğramış bir ülke imajı yaratmıştır. Bu olumsuz algının yıkılması için etkili bir politika izleyen ülke, "post from Japan" adıyla bir uygulama (genel konuşma dilinde ve teknik ifadelerde "aplikasyon" olarak da anılmaktadır) oluşturmuş ve bölgeye giden turistlerin çektikleri fotoğrafları popüler sosyal medya platformlarından biri olan Facebook'ta paylaşmaları istenmiştir. Fotoğrafların beğeni sayısına göre kullanıcıya ücretsiz internet desteği sunulacağı vaadiyle seyahate teşvik sağlanmaya çalışılmıştır (Bayram vd., 2017: 23). Sosyal medyanın destinasyon üzerindeki etkileri araştırmacıların gerçekleştirdiği çalışmalarla desteklenmektedir. Yapılan çalışmalar turistlerin seyahat etmeden önce sosyal medya üzerinden ilgili bölgeye dair içerik paylaşımlarını incelemekte olduklarını, seyahatlerinden sonra deneyimlerini fotoğraf, video vb. destekleyici unsurlar ile paylaştıklarını, bu paylaşımların seyahat tercihini ciddi oranda etkilediğini göstermektedir (Fotis vd., 2012, Eşitti ve Işık, 2015, Terttunen, 2017, Bayram vd., 2018, Granberg, 2019, Başarangil, 2019, Ünal, 2020).

Sosyal medya platformları aracılığıyla tanınan destinasyonlardan biri Isparta'nın Keçiborlu ilçesine bağlı Kuyucak Köyü'nde bulunan lavanta bahçeleridir. Lavantalar köye ekonomik kalkınma sağlaması açısından oldukça önemli bir paya sahiptir (Ongun vd., 2018: 47). Türkiye'deki lavanta üretiminin \%93'ünün gerçekleştirildiği köyde bulunan lavanta bahçeleri insanlar tarafından ilgiyle ziyaret edilmektedir. Bölgeye yapılan turizm faaliyetlerinin artırılması, lavanta ürünlerinin çeşitliliğinin sağlanması, yerel halkın istihdamının gerçekleştirilmesi gibi amaçlar doğrultusunda 2015 yılında Keçiborlu Yardımlaşma Dayanışma ve Eğitim Derneği, 
Keçiborlu Kaymakamlı̆̆1 Köylere Hizmet Götürme Birliği ve Kuyucak Köyü Muhtarlığ tarafından "Gelecek Turizmde" projesi sunulmuş, sunulan proje 2016 yılında faaliyete başlamıştır. Proje kapsamında proje ekibi ve lavanta üretimini gerçekleştiren kadınlar tarafından,

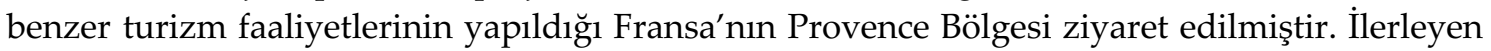
süreçte "Lavanta Kokulu Köy Kadın Girişimciler Kooperatifi" kurulmuş, kadınlardan oluşan üyelere bölgenin tanıtımı, kırsal turizm, kooperatifçilik gibi konularda eğitimler verilmiştir. Sosyal medya platformlarında Kuyucak Köyü'nün görsel içeriklerle desteklenerek paylaşılmasıyla birlikte bölge, ziyaretçilerin ilgi odağı olmaya başlamıştır. Bu paylaşımların bölgeyi tanımlayan anahtar kelimelerle etiketlemeler yapılmasıyla birlikte etkileşim artırılmaktadır. Bölgeyi ziyaret edecek kullanıcılar sosyal medya platformlarında anahtar kelimelerle arama yaparak ilgili içeriklere ulaşabilmekte, köy ile ilgili paylaşımları takip edebilmekte ve detaylı bilgi alabilmektedirler. Dijital mecraların da etkisiyle köye gerçekleştirilen ziyaretlerdeki ve turist sayısındaki artış, insanların bölgeyle ilgili algılarına pozitif yönde etki ettiğini gösterir niteliktedir.

\section{YÖNTEM}

Bu çalışmanın amacı, üniversite öğrencilerinin destinasyon imajı algısı üzerinde sosyal medyanın etkisinin araştırılması olarak belirlenmiştir. Çalışmada, sosyal medya mecralarının aktif kullanıcılarından olan üniversite öğrencilerinin Isparta ili Keçiborlu ilçesine bağlı Kuyucak Köyü sınırları içerisindeki lavanta tarlalarını ziyaretleri öncesi ve sonrasında yöre hakkındaki algıları analiz edilerek, sosyal medyanın bireylerin destinasyon algıları üzerindeki etkileri ortaya konulmaya çalışılmıştır. Çalışmada ayrıca, Kuyucak lavanta turizmi merkezinin tanınırlığının sağlanmasında sosyal medya mecralarının ne ölçüde etkili olduğu ve bu etkinin artırılması için neler yapılabileceği sorularına da yanıt aranmaktadır. Sosyal medya platformları aracılığıyla tanınan destinasyonlardan biri Isparta'nın Keçiborlu ilçesine bağlı Kuyucak Köyü'nde bulunan lavanta bahçeleridir. Lavantanın Isparta ili için bir imaj unsuru haline gelmesi, teknolojiye bağlı olarak özellikle son yıllarda sosyal medya paylaşımlarıyla Kuyucak Köyü'nün popülerleşmesi, bölgede aktif olarak turizm faaliyetlerinin devam ediyor olması, ulusal ve uluslararası çapta ilgi çekici bir destinasyon olması gibi nedenler çalışma alanının Kuyucak Köyü olarak belirlenmesinde etkili olmuştur.

Araştırma evreni Isparta ili sınırları içerisinde yer alan Süleyman Demirel Üniversitesi öğrencileri ile sınırlandırılmıştır. Nitel araştırma yöntemlerinden yarı yapılandırılmış görüşme tekniği kullanılarak gerçekleştirilen bu çalışmanın örneklemi 8'i doktora, 7'si yüksek lisans, 10'u lisans, 7'si ön lisans öğrencisi olan toplam 32 öğrenciyi kapsamaktadır. Katılımcılar nitel araştırma yöntemlerinde sıkça tercih edilen tesadüfi olmayan örnekleme yöntemlerinden amaca yönelik örnekleme tekniği ile belirlenmiştir. Bu teknik, araştırma sorunsalına uygun olacağ düşünülen olaylara, olgulara, nesnelere, kişilere ulaşılarak detaylı bilgi edinilmesine olanak tanımaktadır (Gürbüz ve Şahin, 2014: 132). Bölge ile ilgili deneyimlerinin ve izlenimlerinin irdelenebilmesi için görüşmeye katılanların Kuyucak Lavanta Köyü'nü ziyaret etmiş olma kriterini sağlaması bir gereklilik olarak görülmüş olup bu kıstas verilerin geçerliliğini yükseltmektedir.

Araştırma veri toplama aracı olarak yarı yapılandırılmış soru formu oluşturulmuş, katılımcılarla yüz yüze görüşme/mülakat tekniği kullanılmıştır. Yarı yapılandırılmış mülakat tekniği araştırmacının önceden sormayı planladığı soruları içeren görüşme formunu kullanarak daha sistematik ve karşılaştırılabilir bilgiler elde edilebilmesini kolaylaştırmaktadır. Görüşme tekniğinin güçlü yönleri şu şekilde sıralanabilir (Bal, 2013: 76; Yüksel ve Yüksel, 2004: 156; Kozak, 2018: 84; Yıldırım ve Şimşek, 2018: 133-134): 
- Görüşmecinin görüşülen kişiye kendisiyle ve araştırmasıyla ilgili bilgi vermesi, kişisel bilgilerin gizliliği konusunda açıklama yapması bir güven ortamının oluşturulmasını sağlar.

- Katılımcının soruyu anlamama, yanlış anlama ihtimalleri doğrultusunda detaylı açıklama yapmak mümkündür. Bireyin tutumlarına göre sorular değiştirilebilir, atlanabilir ya da ek sorular sorulabilir. Bu noktada görüşme tekniği büyük oranda esneklik sağlamaktadır.

- Görüşme esnasında araştırmacının ve katılımcının aynı ortamda bulunması, araştırmacının bu ortamı görüşmeye uygun bir biçimde düzenleyebilmesi açısından avantajlıdır. Ortamın kontrolü bizzat araştırmacı tarafından sağlanabilmektedir. Bu sayede katılımcıdan derinlemesine, kolay ve doğru yanıtlar almak mümkün hale gelmekte, neden-sonuç ilişkisinin analizi kolay bir şekilde ortaya konabilmektedir.

- Bir anket çalışmasında katılımcının yanıtları başka referanslar aracılığıyla doldurması, kopyalaması, anketi başka bireylere doldurtması gibi olasılıklar söz konusudur. Bu noktada görüşme tekniğinde ortam üzerinde kontrole sahip olan görüşmeci sorulara verilen yanıtların katılımcıya ait olduğunu teyit etmesinden dolayı anket yöntemiyle elde edilen verilere nazaran geçerliliğinin daha yüksek olduğu söylenebilmektedir.

Araştırmanın yürütüldüğü tarih aralığında küresel çapta bir pandeminin (Covid-19) ortaya çıkması ve eğitim öğretim faaliyetlerinin çevrimiçi yürütülmesi kararının alınmasından dolayı, katılımcılarla yüz yüze yapılması planlanan görüşmelerin bir kısmı çevrimiçi platformlar ve telefon aracılığıyla gerçekleştirilmiştir. 9 Ekim-14 Kasım tarihleri arasında yapılan görüşmelerin 20 'si yüz yüze, 6'sı telefon ile sesli olarak, 6'sı ise çevrimiçi kişilerarası iletişim platformlarından biri olan Whatsapp aracılığıyla görüntülü olarak gerçekleştirilmiştir. Araştırma kapsamında yapılan mülakat öncesinde her bir katılımcıya çalışmanın önemi ve amacı anlatılarak görüşme için uygun yer, tarih ve saat belirlenmiştir. Katılımcılara konuyla ilgili detaylı bilgi verilerek yarı yapılandırılmış soru formunda yer alan 14 adet soru yöneltilmiştir. Görüşmeye başlamadan önce sağlıklı bir iletişimin sağlanması açısından formdaki bazı sorularda yer alan "destinasyon" terimine açiklık getirilmiştir. 32 katılımcıyla minimum 10, maksimum 47 dakika olmak üzere toplam 685 dakika 43 saniye süren görüşmeler gerçekleştirilmiştir. Görüşmelerden elde edilen veriler içerik analizi yöntemiyle analiz edilmiştir. İçerik analizi, iletişim içeriğinin niceleyici, sistematik ve nesnel bir araştırma tekniğidir. İçerik analizinde birbirine benzeyen verilerin bir araya getirilerek anlaşılır bir biçimde yorumlanarak okuyucuya sunulması amaçlanmaktadır (Yıldırım ve Şimşek, 2018: 242). Katılımcıların görüşme formunda bulunan sorularla ilgili görüşleri doğrultusunda tema, alt tema ve kodlar oluşturulmuştur. Çalışmanın geçerliliği için oluşturulan tema ve kodlar uzman görüşleri alınarak değerlendirilmeye tabi tutulmuştur. Alanında uzman kişilerin farklı zamanlarda yaptıkları değerlendirmelerle birlikte temalar ve kodlar anlamlı bir bütün oluşturularak yeniden düzenlenmiştir. 14 soru için 7 tema ve 15 alt tema belirlenerek bulgular yorumlanmıştır.

\section{BULGULAR}

Araştırmanın bu bölümünde öncelikle katılımcıların demografik bilgilerine ait bulgulara yer verilmiştir.

Çalışma kapsamında görüşme gerçekleştirilen üniversite öğrencilerine ait demografik özellikler Tablo 1'de verilmiş olup, tablo incelendiğinde K1, K2, K3...K32 şeklinde kodlanan katılımcıların çoğunluğunun \% 65,6'lık oranla kadınlardan oluştuğu görülmektedir. Katılımcıların yaşları 20 ile 35 arasında değişiklik göstermekte olup yaş ortalaması $26^{\prime}$ dır. Elde edilen bulgulara göre katılımciların 8'i doktora (\%25), 7'si yüksek lisans (\%21,8), 10'u lisans (\%31,2), 7'si ise ön lisans $(\% 21,8)$ düzeyinde öğrenim görmektedirler. 
Tablo 1. Katılımclların Demografik Bilgileri, Görüşme Tarihleri ve Süreleri

\begin{tabular}{|c|c|c|c|c|c|}
\hline Katılımcı Kodu & Cinsiyet & Yaş & Eğitim Durumu & Görüşme Tarihi & $\begin{array}{l}\text { Görüşme Süresi } \\
\text { (Dakika/Saniye) }\end{array}$ \\
\hline K1 & Erkek & 30 & Yüksek Lisans & 09.10 .2020 & $32: 54$ \\
\hline K2 & Kadın & 26 & Doktora & 11.10 .2020 & 18:02 \\
\hline K3 & Kadın & 24 & Lisans & 13.10 .2020 & 11:19 \\
\hline K4 & Erkek & 25 & Yüksek Lisans & 13.10 .2020 & 13:31 \\
\hline K5 & Kadın & 31 & Doktora & 13.10.2020 & 10:31 \\
\hline K6 & Erkek & 31 & Doktora & 13.10.2020 & $13: 24$ \\
\hline K7 & Kadın & 27 & Doktora & 13.10 .2020 & $20: 33$ \\
\hline K8 & Kadın & 27 & Ön Lisans & 13.10 .2020 & $13: 23$ \\
\hline K9 & Kadın & 26 & Lisans & 13.10 .2020 & $26: 25$ \\
\hline K10 & Erkek & 32 & Doktora & 14.10 .2020 & $21: 28$ \\
\hline K11 & Kadın & 20 & Ön Lisans & 15.10 .2020 & $10: 52$ \\
\hline K12 & Erkek & 22 & Ön Lisans & 15.10 .2020 & 16:47 \\
\hline K13 & Kadın & 25 & Yüksek Lisans & 16.10 .2020 & 18:18 \\
\hline K14 & Kadın & 25 & Yüksek Lisans & 16.10 .2020 & 16:08 \\
\hline K15 & Erkek & 35 & Yüksek Lisans & 19.10 .2020 & $20: 12$ \\
\hline K16 & Kadın & 26 & Doktora & 20.10 .2020 & $36: 26$ \\
\hline K17 & Erkek & 24 & Lisans & 21.10 .2020 & $19: 23$ \\
\hline K18 & Kadın & 24 & Lisans & 21.10 .2020 & $28: 38$ \\
\hline K19 & Kadın & 29 & Lisans & 23.10 .2020 & $33: 21$ \\
\hline K20 & Kadın & 24 & Lisans & 23.10 .2020 & $28: 16$ \\
\hline K21 & Kadın & 25 & Yüksek Lisans & 23.10 .2020 & $27: 47$ \\
\hline K22 & Erkek & 33 & Lisans & 23.10 .2020 & $15: 56$ \\
\hline K23 & Kadın & 25 & Lisans & 25.10 .2020 & $32: 50$ \\
\hline K24 & Kadın & 24 & Yüksek Lisans & 25.10 .2020 & $18: 40$ \\
\hline K25 & Kadın & 20 & Ön Lisans & 27.10 .2020 & 13:44 \\
\hline K26 & Kadın & 33 & Doktora & 27.10 .2020 & 19:27 \\
\hline K27 & Erkek & 34 & Doktora & 27.10.2020 & $15: 54$ \\
\hline K28 & Kadın & 23 & Ön Lisans & 07.11 .2020 & $24: 14$ \\
\hline K29 & Erkek & 23 & Lisans & 07.11 .2020 & $27: 01$ \\
\hline K30 & Kadın & 31 & Ön Lisans & 10.11 .2020 & $17: 12$ \\
\hline K31 & Erkek & 22 & Ön Lisans & 10.11 .2020 & $15: 45$ \\
\hline K32 & Kadın & 26 & Lisans & 14.11 .2020 & 47:05 \\
\hline
\end{tabular}

\section{Sosyal Medya Platformlarının Kullanımına İlişkin Bulgular}

Katılımcılara ilk olarak sosyal medya kullanımına yönelik sorular yöneltilmiştir. Bu doğrultuda ilk tema "sosyal medya kullanımı" olarak belirlenmiştir. Soru formunda yer alan ilk soru "Sosyal medya platformlarını ne sıklıkla kullanıyorsunuz?" şeklindedir.

Alt tema olarak belirlenen "Sosyal medya mecralarının ortalama kullanım sıklığı" hakkında verdikleri bilgilere göre 1-30 dakika, 1-5 saat ve 6-9 saat olmak üzere üç kod belirlenmiştir. Sosyal medya platformlarında 1-30 dakika ve 6-9 saat aralığında vakit geçiren kullanıcı oranı \%12,5 ile benzerlik göstermektedir. Ayrıca kullanıcıların sosyal medyada \%75'lik oranla 1-5 saat arası aktif olarak vakit geçirdiklerini söylemek mümkündür. 
Tablo 2. Sosyal Medya Platformlarının Kullanım Sıklığına İlişkin Bulgular

\begin{tabular}{|c|c|c|c|c|c|}
\hline Tema & Alt Tema & Kod & Katılımcı Kodu & İfade S1klığ1 & $\%$ \\
\hline \multirow{3}{*}{ 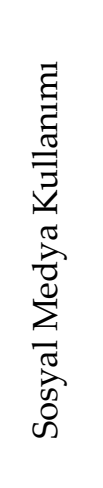 } & \multirow{3}{*}{ 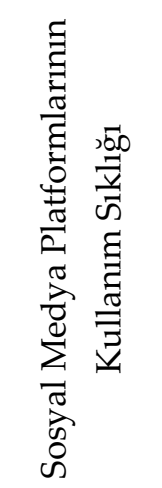 } & 1-30 dakika & $\mathrm{K}(3,4,12,26)$ & 4 & 12,5 \\
\hline & & $1-5$ saat & $\begin{array}{l}\mathrm{K}(2,5,6,7,8,9,10, \\
11,13,14,15,16,17, \\
19,20,21,22,24,25, \\
27,28,29,30,31)\end{array}$ & 24 & 75 \\
\hline & & $6-9$ saat & $\mathrm{K}(1,18,23,32)$ & 4 & 12,5 \\
\hline
\end{tabular}

Görüşme formunda yer alan ikinci soru "En çok hangi sosyal medya platformlarını kullanıyorsunuz?" sorusuna verilen yanıtların analizi için ikinci alt tema "En çok kullanılan sosyal medya platformları" olarak belirlenmiştir. Verilen yanıtlara göre platformların isimlerinin yer aldığ1 yedi kod oluşturulmuştur. Buna göre katılımcıların 28'inin (\%87) Instagram, 22'sinin (\%68) Twitter, 11'inin (\%34) Whatsapp, 9'unun (\%28) Facebook, 8'inin (\%25) Youtube, 2'sinin (\%6) Linkedin, 1'inin (\%3) TikTok platformlarını sık kullandığı sonucuna ulaşılmıştır.

Üçüncü alt tema olarak belirlenen "Sosyal medya platformlarının kullanım amacı", katılımcıların yanıtlarıyla oluşturulan on bir kod kullanılarak analiz edilmiştir. Görüşme formunda yer alan "Sosyal medyayı hangi amaçlarla kullanıyorsunuz?" sorusuna en çok gündem takibi $(\% 46,8)$, diğer kullanıcıların paylaşımlarının takibi $(\% 46,8)$ ve yeni yerler keşfetme $(\% 34,3)$ şeklinde yanıtlar verilmiştir. Bu sırayı iletişim kurma $(\% 28,1)$, eğlenme $(\% 28,1)$, bilgi edinme $(\% 25)$, ilgi alanlarıly ilgili inceleme yapma (\%25), haber takibi $(\% 21,8)$, araştırma yapma (\%21,8), vakit geçirme $(\% 18,7)$, alışveriş yapma $(\% 9,3)$, içerik paylaşımı $(\% 9,3)$ ve ürün satışı $(\% 6,2)$ takip etmektedir. Yanıtlar incelendiğinde sosyal medya platformlarının pek çok amaca hizmet ettiği dolayısıyla kullanıcıların bu platformları tek bir amaçla kullanmadıkları gözlemlenmiştir.

\section{Sosyal Medya Paylaşımlanının Turistlerin Seyahat Tercihine Etkisine İlişkin Bulgular}

Görüşme formunda dördüncü sırada, sosyal medyada paylaşılan içeriklerin potansiyel turistlerin seyahat tercihlerine olan etki düzeyini analiz etmek üzere "Sizce sosyal medya mecralarında paylaşılan içerikler, turistlerin seyahat tercihlerinde ne derece etkilidir?" sorusu yer almaktadır. Yanitlar doğrultusunda "Sosyal medya ve seyahat kararı arasındaki ilişki" teması ve "Sosyal medya paylaşımlarının turistlerin seyahat tercihine etkisi" alt teması oluşturulmuştur.

Bulgulara göre katılımcıların \%78,1'i sosyal medyadaki paylaşımların seyahat tercihlerine yüksek oranda etkisi olduğunu, \%21,8'i bu etkinin normal düzeyde olduğunu düşünmektedir. Yapılan paylaşımların düşük düzeyde etkisinin olduğu ya da hiçbir etkisinin olmadığı konusunda görüş belirten bulunmamaktadır. Yanıtlar incelendiğinde katılımcıların sosyal medya paylaşımlarının turistlerin seyahat tercihlerinde etkisi olduğu yönünde fikir birliğine sahip oldukları görülmektedir. Yaşanılan teknolojik çağın etkisiyle insanların sosyal medya mecralarında aktif olarak yer aldığı, kullanıcıların yapılan paylaşımları yakından takip ettikleri söylenebilir. Yeni destinasyonlar keşfetmek, bu yerler hakkında derinlemesine bilgi edinmek, yapılan paylaşımları 
görmek, seyahat eden kullanıcıların yorumlarını analiz etmek gibi pek çok eylem sosyal medya mecraları vasıtasıyla gerçekleştirilebilmektedir. Bir destinasyona seyahat kararı alma konusunda görselliğin önemi ayrıca vurgulanmıştır. Bölgenin fotoğraflanabilir çekicilikte olmasının ve çok sayıda takipçi kitlesine sahip insanların bölgeyi ziyaret edip paylaşımlarda bulunmasının insanların seyahat tercihleri konusunda önemli kriterler olduğu görülmektedir.

Tablo 3. Sosyal Medya Paylaşımlarının Turistlerin Seyahat Tercihine Etkisine İlişkin Bulgular

\begin{tabular}{|c|c|c|c|c|c|}
\hline Tema & Alt Tema & Kod & Katılımcı Kodu & İfade Sıklığı & $\%$ \\
\hline \multirow{3}{*}{ 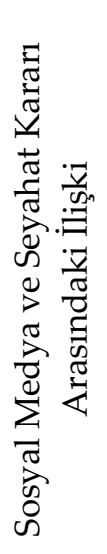 } & \multirow{3}{*}{ 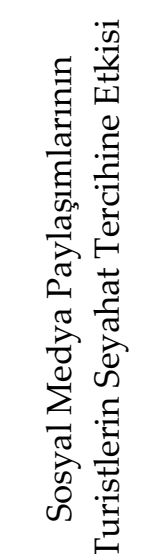 } & $\begin{array}{l}\text { Yüksek düzeyde } \\
\text { etkili }\end{array}$ & $\begin{array}{l}\mathrm{K}(1,2,3,4,5,7,8, \\
9,10,11,12,14,15, \\
16,18,19,21,22,23, \\
24,25,28,30,31,32)\end{array}$ & 25 & 78,1 \\
\hline & & $\begin{array}{l}\text { Normal düzeyde } \\
\text { etkili }\end{array}$ & $\begin{array}{l}\mathrm{K}(6,13,17,20,26, \\
27,29)\end{array}$ & 7 & 21,8 \\
\hline & & $\begin{array}{l}\text { Düşük düzeyde } \\
\text { etkili / Etkisi yok }\end{array}$ & - & - & - \\
\hline
\end{tabular}

\section{Lavanta Kokulu Köy Hakkında Sahip Olunan Bilgiye İlişkin Bulgular}

Üçüncü tema katılımcıların, araştırma evreni olarak belirlenen Kuyucak - Lavanta Kokulu Köy hakkındaki bilgilerini analiz etmek amacıyla "Lavanta Kokulu Köy hakkında sahip olunan bilgi" şeklinde belirlenmiştir. Formda yer alan "Lavanta Kokulu Köy'ü nasıl keşfettiniz?" sorusu için "Lavanta Kokulu Köy'ün keşfedilmesi" alt teması, "Ağızdan ağıza iletişim", "Sosyal medya platformları" ve "Belirsiz" olmak üzere üç adet kod oluşturulmuştur.

Tablo 4. Lavanta Kokulu Köy 'ün Keşfedilmesine İlişkin Bulgular

\begin{tabular}{|c|c|c|c|c|c|}
\hline Tema & Alt Tema & Kod & Katılımcı Kodu & İfade Sıklı̆̆ı & $\%$ \\
\hline \multirow{3}{*}{ 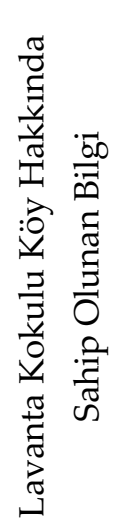 } & \multirow{3}{*}{ 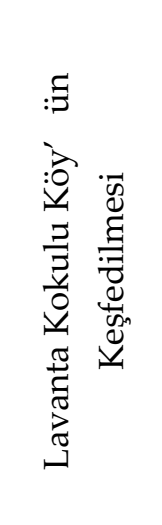 } & $\begin{array}{l}\text { Ağızdan Ağıza } \\
\text { İletişim }\end{array}$ & $\begin{array}{l}\mathrm{K}(3,4,6,7,8,15, \\
17,19,20,23,25,26, \\
27,28,31,32)\end{array}$ & 16 & 50 \\
\hline & & $\begin{array}{l}\text { Sosyal Medya } \\
\text { Platformları }\end{array}$ & $\begin{array}{l}\mathrm{K}(1,2,5,9,10,11, \\
12,14,18,21,22,24, \\
29,30,)\end{array}$ & 14 & 43,7 \\
\hline & & Belirsiz & $\mathrm{K}(13,16)$ & 2 & 6,2 \\
\hline
\end{tabular}


Elde edilen bulgular katılımcıların Lavanta Kokulu Köy'ü \%50 ile ağızdan ağıza iletişim yoluyla, \%43,7 ile sosyal medya platformları aracılığıyla keşfettiği yönündedir. İki katılımcı Lavanta Kokulu Köy'ü nasıl keşfettiklerine dair net bir ifadede bulunmadıkları için üçüncü kod "Belirsiz" $(\% 6,2)$ kategorisine dâhil edilmiştir. Katılımcıların bazıları Ispartalı oldukları ya da Isparta'da ikamet ettikleri için ağızdan ağıza iletişim yoluyla köyün bilincinde olduğunu fakat bölgeyle ilgili araştırma yapmak için sosyal medya platformlarını kullandıklarını belirtmişlerdir. Bunun yanı sıra Ispartalı olan ya da Isparta'da ikamet etmelerine rağmen bölgenin bilincinde olmayan, Lavanta Kokulu Köy'ü dijital mecralardan öğrenen katılımcıların da olduğu tespit edilmiştir. Lavanta Kokulu Köy'ün keşfedilmesine ilişkin bulgular incelendiğinde genellikle sosyal medya platformlarının etkisi olduğu gözlemlenmiştir. \%50'lik kesim tarafından köyün bilincine ağızdan ağıza iletişim yoluyla varıldığı söylenmesine rağmen bölgeyle ilgili detaylı araştırma için yine bu mecraların kullanıldığı belirtilmiştir. Detaylı araştırmanın köyle ilgili etiketlerin (hashtag) kullanılarak yapıldığı dikkat çeken bir diğer unsurdur. Ayrıca Isparta ili sınırları içerisinde yaşayan fakat bölge hakkında bilgi sahibi olmayan katılımciların bu konuda sosyal medyadan yararlandıkları bulgusu, bu mecraların bir turizm destinasyonunu ön plana çıkarma konusundaki gücünü gözler önüne sermektedir.

"Lavanta Kokulu Köy hakkında sahip olunan bilgi" temasının ikinci alt teması köyün ziyaret edilme sebebini analiz etmek üzere "Lavanta Kokulu Köyü ziyaret amacı" olarak belirlenmiştir. Bulguların ortaya konması için "Kuyucak Lavanta Köyü'nü ziyaret etmenize neden olan etkenler nelerdir?" sorusuna yanıt aranmıştır. Verilen yanıtlara göre altı adet kod oluşturulmuştur. Bu yanıtların ilki \%59,3 ile merak olmuştur. Bu sırayı \%12,5 ile gezi, \%9,3 ile özgünlük ve fotoğraf çekimi, \%6,2 ile bilimsel araştırma/iş, \%3,1 ile akraba ziyareti takip etmektedir. Sosyal medya paylaşımlarından görerek köyü ziyaret eden katılımcıların bazıları "Lavanta Kokulu Köy'ün gerçekten sosyal medyada yansıtıldığı gibi mi?" sorusuna yanıt aradıklarını ve bu paylaşımların merak uyandırdığını belirtmişlerdir. Özellikle lavanta bahçelerini içeren görsel paylaşımların bölgeyi ziyarete teşvik ettiği görülmektedir. Çekicilik unsurunun yanında fotoğrafların gerçeği yansıtıp yansıtmadığı ayrıca bir merak konusu olmuş ve bu durum ziyaret sayısında artışa sebep olmuştur. Merak unsuru dışında, turizm faaliyetlerinin gerçekleştirilmesi, köyün kendine özgü bir atmosfere sahip olması, fotoğraf çekimleri yapılıp sosyal medya aracılığıyla diğer insanlarla paylaşılması, akademik çalışmaların gerçekleştirilmesi, ticarî amaçlı seyahatte bulunulması ve yakın çevrenin ziyaret edilmesi gibi unsurlar doğrultusunda köyün pek çok kişi tarafından ziyaret edildiğini söylemek mümkündür.

\section{Sosyal Medya ve Destinasyon İmajı Arasındaki İlişkiye İlişkin Bulgular}

Görüşme soruları içerisinde yer alan yedinci soru "Sosyal medyada yapılan paylaşımların sizin bu bölgeyle ilgili düşüncelerinizin oluşumunda etkisi oldu mu? Neden?" ve sekizinci soru "Bölgeyi ziyaret etmeden önce sosyal medyada yapılan paylaşımlar sonucu oluşan izlenimlerinizle ziyaret sonrası izlenimleriniz arasında bir değişiklik oldu mu? Oldu ise bu değişikliğin sebebi ne olabilir?" olarak belirlenmiştir. Bu sorular ile sosyal medya paylaşımlarının Lavanta Kokulu Köyün imaj oluşumunda etkisinin olup olmadığı, etkisi oldu ise bölgeye gerçekleştirilen ziyaret sonrası bu imajın değişiklik gösterip göstermediğinin tespit edilmesi amaçlanmıştır. Bu noktada "Sosyal medya paylaşımlarının ziyaret öncesi bölge imajına etkisi" ve "sosyal medya paylaşımlarının ziyaret sonrası bölge imajına etkisi" olarak iki alt tema belirlenmiştir.

Tablo 5.'te görüldügü üzere 27 kişi $(\% 84,3)$ sosyal medya paylaşımlarının Lavanta Kokulu Köy ile ilgili düşüncelerin şekillenmesine etki ettiği yönünde ortak bir görüşe sahiptir. 5 kişi $(\% 15,6)$ ise düşüncelerini herhangi bir etki yaratmadığı biçiminde ifade etmiştir. Sosyal medya 
paylaşımları sonrası oluşan izlenimler ile bölgeyi ziyaret sonrası oluşan izlenimler arasında değişiklik olup olmadığı yönünde bulguların ortaya konması için sorulan soruya 20 kişi $(\% 62,5)$ "değişiklik oldu", 12 kişi $(\% 37,5)$ "değişiklik olmadı" biçiminde yorumlarda bulunmuştur.

Tablo 5. Sosyal Medya Paylaşımlarının Ziyaret Öncesi ve Sonrası Bölge İmajına Etkisine İlişkin Bulgular

\begin{tabular}{|c|c|c|c|c|c|}
\hline Tema & Alt Tema & Kod & Katılımcı Kodu & Iffade Sıklığı & $\%$ \\
\hline \multirow{4}{*}{ 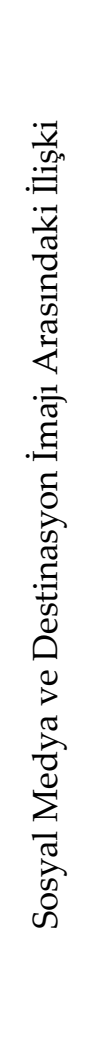 } & \multirow{2}{*}{ 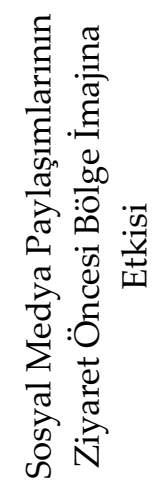 } & Etkisi Var & $\begin{array}{l}\mathrm{K}(1,2,3,4,5,7,9, \\
10,11,12,13,14,15, \\
16,17,18,19,20,21, \\
22,23,24,25,28,29, \\
31,32)\end{array}$ & 27 & 84,3 \\
\hline & & Etkisi Yok & $\mathrm{K}(6,8,26,27,30)$ & 5 & 15,6 \\
\hline & \multirow{2}{*}{ 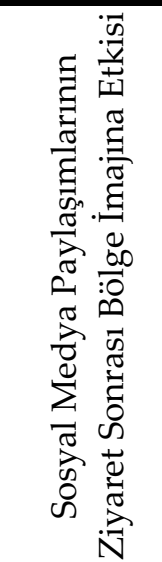 } & Değişiklik Oldu & $\begin{array}{l}\mathrm{K}(2,3,5,6,7,9,12, \\
14,15,16,17,18,20, \\
23,25,27,29,30,31, \\
32)\end{array}$ & 20 & 62,5 \\
\hline & & Değişiklik Olmadı & $\begin{array}{l}\mathrm{K}(1,4,8,10,11,13 \\
19,21,22,24,26,28)\end{array}$ & 12 & 37,5 \\
\hline
\end{tabular}

Elde edilen veriler, sosyal medya paylaşımları ile destinasyon imajı oluşumu arasında yüksek oranda bir ilişki olduğunu göstermektedir. 32 katılımcının 27'si paylaşımlardan etkilenerek bölgeyi ziyaret etme kararı aldıklarını, paylaşımların ilgi uyandırdığını ifade etmiştir. Sosyal medyanın bölgeyle ilgili imaj oluşumu konusunda herhangi bir etki yaratmadığını belirten kullanıcıların ise sosyal medyayı aktif biçimde kullanmadıklarını ifade etmelerinden yola çıkılarak bir etki oluşmamasının çok fazla paylaşım ile karşılaşmamış olduklarından kaynaklandığı şeklinde yorum yapılabilir. Sosyal medyada yapılan içerik paylaşımları ile oluşan izlenimlerle köye yapılan ziyaret sonrası izlenimlerin \%62,5'lik bir oranla değişiklik gösterdiği gözlemlenmiştir. Bu değişikliğin en önemli sebeplerinden birinin fotoğrafların çeşitli fotoğraf düzenleme uygulamalarıyla filtrelenerek paylaşılması olduğu söylenebilir. Dijital mecralardaki görsellerin olduğu gibi yansitılmadığı bu sebeple köye gidildiğinde farklı bir görüntüyle karşılaşıldığı belirtilmiş bu da turistlerin ciddi oranda hayal kırıklığına uğramalarına sebebiyet vermiştir. Bazı katılımcıların bu filtrelemenin bilincinde olarak bölgeye ziyaret gerçekleştirmiş olmaları köyle ilgili izlenimlerinde bir değişiklik yaratmaması konusunda etkili olmuştur. 


\section{Lavanta Kokulu Köyü Ziyaret Deneyimine İlişkin Bulgular}

Beşinci tema Lavanta Kokulu Köye gerçekleştirilen ziyaret deneyiminin analiz edilmesi amacıyla oluşturulmuştur. Bu tema "Lavanta Kokulu Köyü ziyaret deneyimi memnuniyet durumu", "Lavanta Kokulu Köyü ziyaret deneyiminin aktarımı", "Lavanta Kokulu Köyün ziyaret edilmesine yönelik tavsiye" adı altında üç alt temayı içermektedir. Sözü edilen alt temalar turistlerin ilgili bölgeye gerçekleştirdikleri ziyaret deneyiminden memnun kalıp kalmadıklarının, deneyimlerini diğer insanlara aktarma biçimlerinin ve köyün ziyaret edilmesi ile ilgili tavsiyede bulunup bulunmayacaklarının ortaya konması amacıyla belirlenmiştir. Katılımcılara yöneltilen dokuzuncu soru "Kuyucak Lavanta Köyü'nü ziyaret deneyiminizden memnun kaldınız mı? Neden?" olarak belirlenmiştir. Elde edilen bulgular, katılımcıların büyük oranda ziyaretlerinden memnun kaldığı yönündedir. 32 katılımcının 29'u (\%90,6) ziyaretten memnun kaldığını, 3'ü $(\% 9,3)$ ise memnun kalmadığını ifade etmiştir. Çoğu katılımcı köyü doğal, otantik, canlı renkleri içinde barındıran hoş bir yer olarak nitelendirerek memnuniyetlerini belirtmiştir. Yöre halkının turistlere karşı tutumu, farklı bir deneyim olması, Isparta'ya ve ülke turizmine olan katkısı gibi etkenlerin ziyaretçilerin memnuniyetini olumlu yönde etkilediği görülmektedir. Deneyimlerinden memnun kalmadığını belirten katılımcıların memnun kalmama sebepleri arasında beklentilerin karşılanmaması, turistik altyapı eksikliği, sosyal medyada yansıtılanlar ile çelişkili bir durumun söz konusu olması gibi unsurlar yer almaktadır.

Memnuniyet durumunun analizinden sonra bu düşüncelerin aktarımı konusunda bulgular edinebilmek açısından katılımcılara "Kuyucak Lavanta Köyü'nü ziyaret deneyiminizi çevrenizdekilere nasıl aktarırsınız? Bölgenin ziyaret edilmesi konusunda tavsiyede bulunur musunuz?" sorusu yöneltilmiştir. Verilen yanıtlara göre ziyaret deneyimi aktarımı konusunda "Ağızdan ağıza iletişim", "Sosyal medya platformları" ve "Her ikisi de" şeklinde üç alt tema belirlenerek kodlar oluşturulmuştur. Katılımcıların bölgenin diğer insanlar tarafından ziyaret edilmesi konusunda tavsiyede bulunup bulunmayacaklarının analizi için "tavsiye ederim" ve "tavsiye etmem" alt temaları oluşturulmuştur. Buna göre katılımcıların \%46,8 oranla ağızdan ağıza iletişim ile, $\% 15,6$ oranla sosyal medya platformları ile, $\% 37,5$ her iki vasıta ile deneyimlerini diğer insanlara aktaracakları yönünde bulgular elde edilmiştir. Katılımcıların \%90,6'sı köyün ziyaret edilmesi konusunda tavsiyede bulunacaklarını, \%9,3'ü ise tavsiyede bulunmayacaklarını belirtmiştir. Verilen ifadeler incelendiğinde deneyimlerin yakın çevreye aktarılması konusunda daha çok ağızdan ağıza iletişimin tercih edildiği görülmüştür. Deneyimlerin daha geniş kitlelere ulaştırılması, bölgenin merak uyandırması ve yine bu bölgeyle ilgili detaylı bilgi edinilmesi konularında sosyal medya platformlarının daha etkili olduğu sonucu ortaya çıkmaktadır. Bulgulara göre K2 ve K6 koduna sahip katılımciların ziyaret deneyimlerinden memnun kalmamalarına rağmen söz konusu destinasyona ziyaret etmeleri konusunda diğer insanlara "memnun kalmadım ama yine de bölge ziyaret edilebilir" biçiminde tavsiyede bulunacakları gözlemlenmiştir.

\section{Lavanta Kokulu Köy Hakkında Değerlendirmeye İlişkin Bulgular}

Araştırmanın örneklemi olarak belirlenen Kuyucak Lavanta Köyü'nü ziyaret eden üniversite öğrencilerinin ilgili destinasyona dair genel bir değerlendirme yapmaları, tecrübelerine dayanarak bölgeyle ilgili olumlu ve olumsuz unsurların neler olduğunu belirtmeleri istenmiştir. Bulgular soru formundaki on birinci ve on ikinci sorular vasıtasıyla tespit edilmiştir. Yanıtlara göre "Lavanta Kokulu Köy hakkında değerlendirme" altıncı tema olarak belirlenmiştir. Olumlu değerlendirmelerin analizi için "Lavanta Kokulu Köy ile ilgili olumlu unsurlar" alt teması oluşturulmuş olup bu alt tema içerisinde misafirperverlik, otantiklik, altyapı ve üstyapı, yerli üretim, yerel kalkınma, girişimcilik, farklı deneyim, fiyat, Isparta imajı ve aktivite çeşitliliği olmak 
üzere on adet kod yer almaktadır. Bulgulara göre katılımclardan \%62,5'lik oranla misafirperverlik, $\% 56,2^{\prime}$ lik oranla otantiklik ve $\% 46,8^{\prime}$ lik oranla altyapı ve üstyapı yanıtları alınmıştır. Analizlere göre katılımcıların birden fazla olumlu unsur belirttiği gözlemlenmiş olup kodlamalar sorulara verilen yanıtların tekrarlanma sıklığına göre sıralanmıştır. Köyle ilgili olumlu unsurların neler olduğunu açıklayan katılımcların bölgeyle ilgili olumsuz unsurlar da olduğu, bu unsurların geliştirilmesi gerektiği ile ilgili fikir birliğine sahip oldukları gözlemlenmiştir. "Sizce Kuyucak Lavanta Köyü destinasyonu ile ilgili olumsuz unsurlar nelerdir?" sorusuna verilen cevaplar doğrultusunda altyapı ve üstyapı yetersizliği, ürün çeşitlendirme eksikliği, aktivite çeşitliliğinin yetersizliği, fotoğrafların yanıltıcılığı, tanıtım eksikliği, yerel halkın turizm bilincinin yetersizliği, fiyatların yüksekliği ve popülerleşme tehdidi şeklinde kodlar belirlenmiştir. Lavanta Kokulu Köy ile ilgili en temel olumsuz unsurun altyap1 ve üstyapı yetersizliği olduğu söylenebilir. İfade sıklı̆̆ının üst düzeyde olması (\%93,7), söz konusu problemin ciddiyetini ortaya koyar niteliktedir. Bu eksikliği \%25 ile ürün çeşitlendirme eksikliği takip etmektedir. Katılımcılar Lavanta Kokulu Köy ile ilgili olumsuz unsurların içerisine genel çerçevede konaklama ve yiyecek-içecek işletme sayılarındaki yetersizlikleri dâhil etmişlerdir. Ayrıca ziyaret sürelerini uzatmaya elverişli bir ortam olmadığını, dinlenmek, alternatif yiyecekler tüketmek ve farklı aktiviteler gerçekleştirmek için yetersizlikler bulunduğunu belirtmişlerdir. Köy içerisindeki altyapı eksiklikleri, ulaşım konusunda yaşanan sıkıntı ifade edilen diğer olumsuz unsurlardır. Yanıtlar arasında altyapı ve üstyapı konusunda iyileştirmelerin doğal ortamın bozulmadan yapılması gerektiği aksi halde popülerleşen bu destinasyonun özgünlügünü kaybedeceği yönünde ifadeler bulunmaktadır. Bazı katılımcıların, yöre halkının turizm sektörüyle ilgili yeterli bilince ulaşmadıkları konusunda bir düşünceye sahip oldukları görülmektedir. Yapılan analiz ile turizm faaliyetlerini gerçekleştirmek üzere bölgeyi ziyaret eden turistlerin belirttiği olumsuzlukların dikkate alındığ 1 ve giderildiği takdirde, köy ile ilgili izlenimlerin olumlu yönde şekilleneceği sonucu çıkarılabilir.

"Lavanta Kokulu Köy hakkında değerlendirme" temasının son alt teması Lavanta Kokulu Köy'ün tanınırlı̆̆ının artırılması hakkındaki görüşlerin elde edilmesi için hazırlanan soru dâhilinde oluşturulmuştur. Bu doğrultuda katılımcilara “Kuyucak Lavanta Köyü'nün tanınırlığını artırmak için neler yapılabilir?" sorusu yöneltilmiştir. Yanıtlara göre dokuz adet kod oluşturulmuştur. Yöneltilen soruya 23 kişi $(\% 71,8)$ sosyal medya platformlarından yararlanılmalı, 14 kişi $(\% 43,7)$ sponsorluk çalışmaları yürütülmeli, 14 kişi $(\% 43,7)$ aktiviteler konusunda çeşitlilik yaratılmalı, 12 kişi $(\% 37,5)$ kitle iletişim araçları kullanılmalı, 11 kişi $(\% 34,3)$ tanıtım faaliyetleri gerçekleştirilmeli, 11 kişi $(\% 34,3)$ altyapı ve üstyapı çalı̧̧malarında iyileştirmeler yapılmall, 7 kişi $(\% 21,8)$ gezi faaliyetleri düzenlenmeli, 6 kişi $(\% 18,7)$ turizm bilinci oluşturulmalı ve 1 kişi $(\% 3,1)$ akademik çalışmalar yürütülmeli yanıtlarını vermiştir. Lavanta Kokulu Köy'ün tanınmasında sosyal medyanın etkisinin fazla olduğu konusunda ortak bir görüş bulunmaktadır. Bu doğrultuda sosyal medya platformlarının bölgenin geniş kitlelere ulaştırılması konusunda önemli bir araç olacağı ifade edilmiştir. Katılımcılar, sosyal medya mecralarında takipçi sayısı fazla olan kişilerin köye davet edilmesinin bir avantaj olacağı düşüncesine sahiptir. Bazı katılımcılar sosyal medyayı kullanmayan kişilerin de bulunduğunu, onlara hitap edecek tanıtım faaliyetlerinin de gerçekleştirilmesi gerektiğini belirtmiştir. Köyde fotoğraf çekimi dışında turistlerin ilgisini çekecek alternatif faaliyetlerin düzenlenmesini bir gereklilik olarak gören katılımcılar, bölgede festival, defile, yarışma gibi etkinliklerin bu konuda fayda sağlayabileceği görüşündedir. 


\section{Isparta İli İmajına İlişkin Bulgular}

Görüşme formunda yer alan son soru Isparta'nın sahip olduğu turizm değerleri hakkındaki katılımcı bilgilerini ölçmek ve Isparta'nın genel anlamda nasıl bir imaj oluşturduğunu analiz etmek amacıyla hazırlanan "Isparta' yı bir turizm destinasyonu olarak düşündüğünüzde, aklınıza şehrin sahip olduğu hangi değerler gelmektedir?" sorusudur. Bu kapsamda "Isparta ili imajı" biçiminde bir tema, "Isparta'nın turistik değerleri" biçiminde bir alt tema oluşturulmuştur. Katılımclardan alınan yanıtlar doğrultusunda on altı adet kod belirlenmiştir.

30 katılımcı Isparta'nın sahip olduğu turistik değerler sorusuna \%93,7'lik oranla Eğirdir yanıtını vermiştir. 21 kişi Isparta'nın Göller Bölgesi içerisinde bulunması dolayısıyla pek çok göle, bu gölleri içerisinde barındıran tabiat parkları ve milli parklara ev sahipliği yaptığını belirtmiştir. Gölcük Tabiat Parkı, Aksu-Başpınar Tabiat Parkı, Kovada Gölü Milli Parkı, Şarkikaraağaç Kızıldağ Milli Parkı, Yazılı Kanyon Milli Parkı verilen örneklerden bazılarıdır. \%59,3 oranla 19 kişi gülün Isparta' da bir imaj unsuru olduğu ve şehrin gül bahçeleriyle anıldığı şeklinde görüşleri bulunmaktadır. Katılımcların yarısının ise araştırmaya konu olan lavanta ve Kuyucak lavanta bahçelerinin Isparta'nın turistik değerleri arasında yer aldığını belirttiği görülmektedir. Şehir içerisinde yer alan antik kentler (Prostanne Antik Kenti, Psidia Antik Kenti), Davraz Kayak Merkezi, mesirelik alanlar (Gökçay, Ayazmana), müze ve medreseler (Isparta Müzesi, Etnografya Halı ve Kilim Müzesi, Süleyman Demirel Demokrasi Müzesi, Atabey Gazi Ertokuş Medresesi), mağaralar (Aksu Zindan Mağarası), şehir merkezi (Bedesten Çarşısı, Tarihi Üzüm Pazarı), Isparta halısı, Yalvaç ilçesi, elma bahçeleri, Kuleönü, at çiftlikleri (Atabey, Gönen), katılımcıların Isparta'nın turizm değerleri olarak nitelendirdiği diğer yerlerdir. Verilen yanıtlar ile söz konusu listeye Burdur' da bulunan Salda Gölü de dâhil edilmiştir. Katılımcıların bazıları Salda Gölü'nün Burdur'da yer aldığını bildiklerini ifade etmiş fakat buranın Isparta'yla da anıldığının altını çizmiştir.

Isparta'nın turizm değerleriyle ilgili değerlendirmeler incelendiğinde insanların zihninde genel anlamda bölgenin olumlu bir imaj yarattığı sonucu çıkarılabilmektedir. Bu olumlu imajın yalnızca Isparta'yı ziyaret eden turistlerin zihinlerinde oluşması, ülke genelinde kentin sahip olduğu değerlerin yeterince tanınmıyor olması elde edilen bulgular arasındadır. Isparta'nın turizm değerleri sorulduğunda Lavanta Kokulu Köy ile ilgili düşüncelerini ifade etmeleri amacıyla görüşülen 32 kişiden yalnızca 16'sının lavanta bahçelerinden söz etmesi dikkat çeken bir diğer bulgudur. Kentin sahip olduğu değerlerin tanınması konusunda katılımcılar sosyal medya platformlarının aktif olarak kullanılması gerektiğini belirtmiştir. Yapılan yorumlar, bir destinasyonun geniş kitlelerce tanınırlı̆̆ının sağlanması ve olumlu bir imajın oluşması konusunda sosyal medyanın gücünü destekler niteliktedir.

\section{TARTIŞMA, SONUÇ ve ÖNERİLER}

Turizm faaliyetlerini gerçekleştirmek üzere seyahat eden turistler, seyahat tecrübeleri sonrasında bölgeyle ilgili olumlu ve olumsuz yönde izlenimlere sahip olmakta ve bu izlenimlerini bölgeye ziyaret edecek olan ya da ziyaret etme potansiyeline sahip olan kişilerle paylaşma ihtiyacı hissetmektedirler. Bu paylaşımlarıyla seyahat sonrasında destinasyonla ilgili oluşan algılarını diğer insanlara yansıtarak onların seyahat kararlarına doğrudan etki etmektedirler. Bu doğrultuda destinasyon imajının, turistik bir bölgenin tanınırlığının ve sürdürülebilirliğinin sağlanması açısından öneminin yadsınamaz bir gerçek olduğu söylenebilir. Destinasyon imaj oluşumuna etki eden faktörler arasında sosyal medya platformları üst sıralarda yer almaktadır. Teknoloji çağı ile birlikte interneti aktif bir biçimde kullanmaya başlayan insanlar seyahat kararı almadan önce bu platformlara başvurmaktadır. Sosyal medya mecralarında paylaşılan 
fotoğraflar, videolar, bilgiler, bölgeyle ilgili yapılan olumlu ve olumsuz yorumlar turistlerin seyahat kararı almalarında ve seyahat edilecek bölgeyle ilgili genel bir izlenime sahip olmalarında yol göstericidir. Bu çalışma sosyal medyanın, bir destinasyon ile ilgili imajın oluşmasına ne düzeyde etki ettiğini tespit etmek amacıyla gerçekleştirilmiştir. Bu etkinin artırılması için neler yapılabileceğinin belirlenmesi ve çalışma alanı olarak belirlenen Isparta Keçiborlu'da bulunan Kuyucak Lavanta Köyü'ne ziyaret eden turistlerin, ziyaret öncesi ve sonrası algılarının analiz edilmesi çalışmanın diğer amaçları arasında yer almaktadır. Ayrıca nitel araştırma yöntemlerinden yarı yapılandırılmış görüşme tekniği kullanılarak gerçekleştirilen bu çalışmada, araştırma örneklemi olarak belirlenen üniversite öğrencilerine yöneltilen sorulardan yola çıkılarak lavantanın ve lavanta turizminin Isparta ili için bir imaj unsuru olup olmadığ tespit edilmeye çalışılmıştır. Bulgular sosyal medya platformlarının aktif olarak kullanıldığını, kullanıcıların gündem takibi, kullanıcı paylaşımlarının takibi, haber takibi, yeni yerler keşfetme, iletişim kurma, bilgi edinme, araştırma yapma, eğlenme, vakit geçirme, alışveriş yapma, içerik paylaşma, ürün satışı ve kullanıcıların ilgi alanlarıyla ilgili incelemelerde bulunmaları gibi amaçlar doğrultusunda bu mecralarda zaman geçirdiklerini göstermektedir. Buna göre sosyal medya platformlarının altyapısının birçok amaca hizmet edecek şekilde tasarlandığı, bu olanağın söz konusu platformlarda geçirilen zaman diliminin fazla olmasında rol oynadığ çıkarımı yapılabilir. Araştırma bulgularından elde edilen bir diğer sonuç ise, sosyal medya mecralarında paylaşılan içeriklerin, bireylerin seyahat tercihlerine önemli ölçüde etki ettiğidir. Kullanıcılar seyahat rotalarını keşfetmek, bu bölgelerle ilgili araştırma yapmak, seyahat deneyimleriyle ilgili yapılan yorumları incelemek gibi imkânlara çeşitli sosyal medya uygulamaları sayesinde sahip olmaktadırlar. Kullanıcılar tarafından yapılan bu araştırmalar, bireylerin bölgeye seyahat edip etmeme konusunda vereceği kararları etkilemektedir. Yanıtlar incelendiğinde bu etkinin özellikle görsel içerikli paylaşımlardan kaynaklandığı sonucuna ulaşılmıştır. Katılımcılar fotoğraf çekimi yapma ve bu fotoğrafları dijital mecralarda paylaşabilme olanağı tanıyan yerlerin merak uyandırdığı, bölgenin fotoğraflanabilir olmasının ziyarete teşvik etme konusunda etkili olduğu görüşündedir. Yapılan fotoğraf paylaşımları bölgeye olan ilgiyi artırma noktasında pozitif anlamda etkili olsa da söz konusu unsur negatif bir etki de yaratabilmektedir. Fotoğrafların olduğu gibi paylaşılmaması, çeşitli programlar aracilığıyla çekici gösterilerek kullanıcılara sunulması ziyaret esnasında hayal kırıklığı yaşanmasına sebep olmaktadır. Verilen yanitlara göre sosyal medyada yapılan paylaşımlar ile oluşan izlenimlerle köye gerçekleştirilen seyahat sonrası izlenimler arasında değişiklik olduğunun tespiti bu önermeyi desteklemektedir. $\mathrm{Bu}$ değişikliğin fotoğrafların, fotoğraf düzenleme uygulamalarıyla filtrelenerek paylaşılmasından kaynaklandığı çoğu katılımcının ortak görüşüdür. Bölgedeki lavanta tarlalarının olduğu gibi yansıtılmadığı bu sebeple köye gidildiğinde farklı bir görüntüyle karşılaşıldığı belirtilmiş ve bu durum turistlerin hayal kırıklığına uğramalarına sebebiyet vermiştir. Ziyaret öncesi sosyal medya paylaşımları sayesinde oluşan olumlu imajın, ziyaret sonrasında yine bu paylaşımlar sebebiyle olumsuz yönde değişiklik göstermesi dikkat çekmektedir. Yapılan filtreli paylaşımlar bölge imajını geliştirme konusunda etkili olsa da turistlerin ziyaretlerinden sonra yaşadıkları "kandırılmış hissi" imaja olumsuz etki olarak dönüş yapmaktadır. Bu noktada yaşanılan olumsuz deneyimin, duygu ve düşüncelerin çeşitli mecralar aracılığıyla paylaşılması durumunda potansiyel turistlerin düşüncelerinin de ciddi oranda şekilleneceği göz önünde bulundurulmalıdır.

Katılımcların Lavanta Kokulu Köyü ağızdan ağıza iletişim ve sosyal medya platformları vasıtasıyla keşfettikleri gözlemlenmiştir. Katılımcıların bazıları Isparta' da ikamet ettikleri ya da Ispartalı oldukları için ağızdan ağıza iletişim yoluyla köyü keşfettiklerini belirtmiş olup köyle ilgili detaylı bilgi sahibi olmak için sosyal medya platformlarına ihtiyaç duyduklarını söylemişlerdir. Bununla birlikte aynı kategoride bulunan bazı katılımcıların Isparta'da yaşıyor olmalarına rağmen bölgeyi sosyal medya yoluyla öğrendikleri bulgular arasında yer almaktadır. 
Bununla birlikte aynı kategoride bulunan bazı katılımcıların Isparta'da yaşıyor olmalarına rağmen bölgeyi sosyal medya yoluyla öğrendikleri bulgular arasında yer almaktadır. Ayrıca çoğu katılımcı bölgenin bilincine ağızdan ağıza iletişim yoluyla varmanın oraya gitme konusunda yeterli bir etken olmadığını, bu şekilde köyün sıradan bir tarladan oluştuğu algısı yaratabileceğini, görsel unsurların bu konuda cezbedici olduğunu düşünmektedir. Bulgulara göre bir destinasyonun tanınması için ilgili turizm mahalline yakın bir bölgede yaşam sürüyor olmanın ve sözlü iletişimin yeterli olmadığı, bu doğrultuda detaylı bilgi sahibi olmak için dijital mecralara başvurulduğu sonucuna ulaşılabilir. Hem keşfetme hem de derinlemesine bilgi edinme açısından tercih edilen bu mecralar aracılığıyla ulaşılan sonuçların doğru, güvenilir ve tutarlı olması bölge imajı açısından oldukça önemlidir. Bu sebeple yapay ve yanıltıcı içerik paylaşımlarının ilgili kurum ve kuruluşlar tarafından denetlenmesi ile bu olumsuzlukların önüne geçilebilir. Köyün ziyaret edilme nedenleri arasında merak unsuru ön plandadır. Bu algının oluşmasında yine sosyal medya mecralarında paylaşılan fotoğrafların etkili olduğu gözlemlenmiştir. Ziyaretçiler bölgenin gerçekten sosyal medyada yansıtıldığı gibi büyüleyici, canlı, mor rengine bürünmüş bir yer olup olmadığı, Lavanta Kokulu Köy olarak anılan köyde ismiyle tutarlı olacak şekilde gerçekten lavanta kokularının yoğun bir şekilde hissedilip hissedilmediği gibi sorulara yanıt arayışına girdiklerini ifade etmişlerdir. Bununla birlikte bölgeyi gezmek, özgün bir konsepte sahip olan bir yeri deneyimlemek, akraba ziyareti, akademik çalışmaların yapılması ve ticarî amaçlı seyahatte bulunulması gibi etkenler köyü ziyaret etme amaçları arasında yer almaktadır. Ayrıca katılımcılar bölgede fotoğraf çekimi yapmak ve bu fotoğrafları sosyal medya mecralarında paylaşabilmek için bu destinasyona gittiklerini belirtmiştir. Elde edilen veriler bir turizm destinasyonunun farkına varılması ve bu bölgeyle ilgili derinlemesine bilgi alınabilmesi konusunda sosyal medyanın güçlü bir mecra olduğunu gösterir niteliktedir. Ayrıca bölgenin görsel çekiciliğinin ön planda olması ve turistlerin ilgili bölgenin fotoğraflama ve dijital platformlarda paylaşma isteği uyandırması ziyarete teşvik ve imaj oluşturma açısından önem arz etmektedir. Köy ile ilgili olumlu unsurlar arasında misafirperverlik, otantiklik, altyapı ve üstyapı, köy halkı tarafından üretilen lavantalı sabun, kolonya, yă̆, krem gibi ürünlerin bulunması, lavantayı dondurma, kahve, çay, bal, gazoz gibi yiyecek ve içeceklere entegre etmeleri, yöreye özgü hediyelik eşyaların bulunması, köyün turizme kazandırılmasıyla birlikte sağlanan yerel kalkınma, girişimcilik faaliyetleri, ziyaretçilerin farklı bir bölgeyi tecrübe etmeleri, fiyat skalası, köyün Isparta imajına olan olumlu etkisi ve birçok aktivitenin gerçekleştirildiği bölge olması yer almaktadır. Olumsuz unsurlar ise altyapı ve üstyapı yetersizliği, ürün çeşitlendirme eksikliği, aktivite çeşitliliğinin yetersizliği, fotoğrafların yanıltıcılığı, tanıtım eksikliği, yerel halkın turizm bilincinin yetersizliği, fiyatların yüksekliği ve popülerleşme tehdidi şeklindedir. Konaklama ve yiyecek-içecek işletme sayılarındaki yetersizlikler, ziyaret süresini uzatmaya elverişli bir ortam olmaması, dinlenmek, alternatif yiyecekler tüketmek ve farklı aktiviteler gerçekleştirmek için yetersizlikler bulunması değinilen önemli eksikliklerdir. Katılımcılar köy içerisindeki altyapı eksikliklerinin, ulaşım konusunda sıkıntının söz konusu olduğunu belirtmekte olup bu konuda iyileştirmeler yapılması gerektiği görüşündedirler. Bu noktada köy imajını olumsuz etkileyen unsurların giderilmesi hususunda çalışmaların yapılması gerektiği görülmektedir. Belirtilen olumsuz unsurlara rağmen katılımcıların büyük bir çoğunluğu $(\% 90,6)$, bölgeyi ziyaretlerinden memnun kaldıklarını belirtmişlerdir. Memnuniyete etki eden faktörlerin köyün doğal, otantik, canlı renkleri içinde barındıran hoş bir yer olması, yerel halkın turistlere karşı tutumu, farklı bir deneyim olması, Isparta'ya ve ülke turizmine olan katkısı olduğu anlaşılmıştır. Deneyimlerinden memnun kalmadığını belirten katılımclar $(\% 9,3)$, köyle ilgili beklentilerinin karşılığını alamadıkları, turistik altyapının yetersiz olduğu, sosyal medyada yansıtılanlar ile çelişkili bir durum olduğu görüşündedir. Memnuniyetlerini belirten katılımcılar bölgenin ziyaret edilmesi konusunda tavsiyede bulunacaklarını ifade etmiştir. Bazı katılımcıların deneyimlerinden memnun 
kalmamalarına rağmen yine de gidilip görülmesi gereken bir yer şeklinde düşünceye sahip olmaları dolayısıyla ziyaret tavsiyesinde bulunacaklarını belirtmeleri dikkat çekmektedir.

Köyün tanınırlığının artırılması konusunda sosyal medya platformlarından yararlanılmalı, sponsorluk çalışmaları yürütülmeli, aktiviteler konusunda çeşitlilik yaratılmalı, kitle iletişim araçları kullanılmalı, tanıtım faaliyetleri gerçekleştirilmeli, altyapı ve üstyapı çalışmalarında iyileştirmeler yapılmalı, gezi faaliyetleri düzenlenmeli, turizm bilinci oluşturulmalı ve akademik çalışmalar yürütülmeli şeklinde yanıtlar alınmıştır. Verilere göre sosyal medya platformlarının bölgenin geniş kitlelere ulaştırılması konusunda önemli bir araç olacağı sonucuna ulaşılmıştır. Katılımcılar, sosyal medya mecralarında takipçi sayısı fazla olan kişilerin köye davet edilmesinin bir avantaj olacağı düşüncesine sahiptir. Ayrıca sosyal medyayı kullanmayan bir kitlenin de bulunduğu, onlara hitap edecek tanıtım faaliyetlerinin de gerçekleştirilmesi gerektiği hususuna değinilmiştir. Köyde fotoğraf çekimi dışında festival, defile, yarışma gibi etkinliklerin düzenlenmesinin bölgenin tanınırlığı ve devamlılığının sağlanmasında etkili olacağı ifade edilmiştir. Katılımcılar tarafından dile getirilen bu ifadeler, Ongun vd., (2015) tarafından gerçekleştirilen çalışmadan elde edilen bulgularla benzerlik göstermektedir. Bununla birlikte, lavantaların toplanması ve yağının çıkarılması gibi faaliyetlerin tur programlarına dâhil edilmesi hem bölgenin imajını olumlu yönde etkilemesi hem de bölgede gerçekleştirilecek konaklama süresinin uzatılması açısından önem arz etmektedir. Isparta'nın sahip olduğu turistik değerlere katılımcılar tarafından Eğirdir, Gölcük Tabiat Parkı, Aksu-Başpınar Tabiat Parkı, Kovada Gölü Milli Parkı, Şarkikaraağaç Kızıldağ Milli Parkı, Yazılı Kanyon Milli Parkı gibi yanıtlar verilmiştir. Ayrıca gülün Isparta'da bir imaj unsuru olduğu ve şehrin gül bahçeleriyle anıldığı şeklinde görüşler bulunmaktadır. Katılımcıların \%50'si lavanta ve Kuyucak lavanta bahçelerinin Isparta'nın turistik değerleri arasında yer aldığını belirtmiştir. Lavanta Kokulu Köy ile ilgili düşüncelerini ifade etmeleri amacıyla görüşülen kişilerin yarısının lavanta bahçelerinden söz etmesi dikkat çeken bir diğer bulgudur. Bu bulgu doğrultusunda Lavanta Kokulu Köy ile Isparta'nın yeteri kadar özdeşleşmediği, lavanta bitkisinin henüz gül bitkisi kadar imaj unsuru oluşturmadığı şeklinde bir çıkarımda bulunulabilir. Burdur sınırları içerisinde yer almasına rağmen katılımcılardan Salda Gölü yanıtı alınması dikkat çeken bir husustur. Bu yanıtın verilmesinde Salda Gölü'nün özellikle sosyal medya mecralarında daha çok Isparta ile anılmasının etkili olduğu belirtilmiştir. Aynı kent içerisinde yer almamasına rağmen yakın bölgede yer alan ve seyahat rotalarına dâhil edilen bir destinasyonun sosyal medya sayesinde Isparta ile anılması bu mecranın gücünü gösterir niteliktedir. Yanıtlar doğrultusunda Isparta'nın olumlu bir imaja sahip olduğu, birçok turizm değerine sahip olduğu fakat bu değerlerin bilincine yeterince varılmadığı dile getirilmiştir. Ayrıca başta yerel halk olmak üzere kamu ve özel sektör turizm paydaşlarının şehrin değerlerine sahip çıkmaları ve bu konuda çalışmalar yürütmeleri konusunda görüşler mevcuttur. Bu çalışmaların yürütülmesinde sosyal medyanın kullanılmasının gereklilik olduğunu ifade eden katılımcılar kentin bu şekilde ülke ve dünya çapında tanıtımının ve imaj oluşturulmasının mümkün olacağı konusunda ortak bir görüşe sahiptir. Araştırma bulgularına göre lavanta bahçelerinin bulunduğu bölge içerisinde eksiklikler bulunmasına rağmen genel olarak olumlu bir izlenim yaratmaktadır. Bu izlenimin oluşmasında ve bölgenin popüler seyahat rotalarından biri haline gelmesinde sosyal medyanın payının büyük olduğu tespit edilmiştir. Bu bulgu, Çevik ve Sariipek (2019) tarafından yapılan çalışma bulgularıla tutarlılık göstermektedir. Katılımcıların bölge ile ilgili bilgi sahibi olmaları konusunda sosyal medya platformlarından yararlandığı, görsel çekiciliğin önemli bir motivasyon kaynağı olduğu ve birçok kullanıcının fotoğraf çekme ve bu fotoğrafları sosyal medya platformlarında paylaşma amacıyla köyü ziyaret ettiği sonuçlarına ulaşılmıştır. Nitekim Giray ve arkadaşlarının (2019) gerçekleştirdiği araştırma bulguları, bu çalışmadan elde edilen sonuçları desteklemektedir. Araştırmadan elde edilen sonuçlar doğrultusunda Lavanta Kokulu Köy ismiyle anılan Kuyucak Köyü'nün daha fazla turist tarafından ağırlanmasını, dünya çapında 
bilinen bir destinasyon konumuna getirerek ve daha güçlü bir imaj oluşumunu sağlayacak bazı öneriler şöyle sıralanabilir:

-Altyapı ve üstyapı çalışmaları artırılabilir. Köyün dokusunun bozulmamasına dikkat edilerek yol çalışmalarının yapılması önerilebilir. Ziyaretçilerin ihtiyaçlarını giderebilecekleri ve dinlenebilecekleri hijyenik ortamların, nezih yiyecek içecek işletmelerinin yer almaması önemli eksikliklerdir. Bu doğrultuda köy içerisindeki evler, tesisler ve diğer mekânlar yeniden düzenlenebilir. Düzenlemelerin köyün doğal yapısına zarar vermeden yapılması göz önünde bulundurulmalıdir.

-Bölgenin ulusal ve uluslararası çapta tanınırlığının sağlanması için reklam ve tanıtım faaliyetlerine ağırlık verilebilir. Turist talebinin artırılması için uygulanacak çalışmaların taşıma kapasitesini aşmayacak şekilde planlanmasına özen gösterilmelidir. Bununla birlikte son zamanlarda sosyal medyanın etkisiyle alternatif turizme olan talebin artışından yola çıkılarak yakın illerde yer alan turizm destinasyonlarının (Burdur-Salda Gölü, Burdur-Lisinia Akçaköy Lavanta Deresi, Isparta-Kuyucak Köyü, Isparta-Yalvaç, Antalya) da dâhil edildiği seyahat rotaları oluşturulabilir. Destinasyon ağı genişletilerek Kuyucak ile birlikte Isparta turizminin ve imajının gelişimi desteklenebilir. Aynı zamanda çevre illerde turizmin canlandırılması sağlanabilir.

-Köy içerisinde aktif olarak tercih edilen fotoğraf çekim etkinlikleri dışında alternatif aktiviteler düzenlenerek turistlerin memnuniyet düzeyleri ve ziyaret süreleri artırılabilir. Son zamanlarda farklı illerde lavanta bahçelerinin oluşturulup bu bahçelerin turizm kapsamında değerlendirilmeye başlanması göz önünde bulundurularak Kuyucak Köyü'nü çekici kılacak etkinliklerin gerçekleştirilmesi gerekmektedir. Bu noktada turistlerin lavantalı ürünlerin yapımı, lavantanın hasat edilmesi gibi konularda bilgilenecekleri, yerinde deneyimleyecekleri faaliyetler düzenlenebilir.

-Köyde yer alan stantlarda yalnızca lavanta ürünlerine ve bölgeye özgü ürünlere yer verilmesi önerilebilir. Lavanta bahçelerine yapılan bir ziyaret esnasında gül ürünleriyle karşılaşılması, bir ürünün Kuyucak Köyü dışında alternatif yerlerde (bakkal, market, hediyelik dükkân vb. işletmeler) temin edilebilir olması birer dezavantaj olarak nitelendirilebilir. Bu unsurların bölgenin otantikliğinin ve imajının korunması hususunda dikkate alınması önerilmektedir.

-Kamu ve özel sektör turizm paydaşlarının desteğiyle sosyal medya çalışmalarına ağırlık verilebilir. Dijital platformlar üzerinden tatil çekilişleri düzenlenerek seyahate teşvik sağlanabilir.

-Bölgeyi koruma bilincinin ve turizm bilincinin artırılması konularında yerel halka yönelik düzenlenen eğitimler artırılabilir.

-Kent içerisinde yer alan Süleyman Demirel Üniversitesi ve Isparta Uygulamalı Bilimler Üniversitesi bünyesinde görev alan başta turizm akademisyenleri olmak üzere bilim insanları tarafından bölge ile ilgili seminerler, konferanslar düzenlenerek köy ile ilgili tanıtım çalışmaları desteklenebilir.

-Görsel çekiciliğin imaja olan etkisinden yola çıkılarak, destinasyonun dijital platformlarda daha çok görsel içeriklerle tanıtılması sağlanabilir.

Bu çalışmanın bulguları, Kuyucak Lavanta Köyü'nü ziyaret eden Süleyman Demirel Üniversitesi öğrencilerinin oluşturduğu sınırlı sayıda örneklem grubu ile elde edilmiştir. İleriye yönelik olarak, nitel araştırma yöntemlerinden yararlanılarak gerçekleştirilen bu çalışma farklı analiz yöntemleriyle, örneklem sayısı genişletilerek tekrarlanabilir. Araştırma evreni Kuyucak Lavanta Köyü olarak belirlenen çalışmanın benzeri alternatif bir destinasyona uyarlanabilir. Literatür 
incelendiğinde lavanta turizmi destinasyonlarını ziyaret eden turistlerin algılarının irdelendiği çalışmaların sınırlı sayıda olması dolayısıyla bu çalışmanın literatüre katkı sağlayacağı öngörülmektedir. Ayrıca bu araştırmanın lavanta turizmi kapsamında faaliyet gösteren sektör çalışanlarının ve kurumların geleceğe yönelik planlamalarında yol gösterici olacağ düşünülmektedir.

\section{KAYNAKÇA}

Atay, L. (2003). Turistik Destinasyon Pazarlaması ve Bir Alan Uygulaması, Yayınlanmamış Doktora Tezi, Dokuz Eylül Üniversitesi, İzmir.

Bal, H. (2013). Nitel Araştırma Yöntemi: Gözlem, Görüşme, Odak Grup, Sözlü Tarih, İçerik Analizi, Söylem Analizi, Isparta: Fakülte Kitabevi.

Başarangil, İ. (2019). Sosyal Medyanın Tatil Tercihlerine Etkisi: Kırklareli Üniversitesi Turizm Fakültesi Öğrencileri Üzerine Bir Araştırma, Journal of Tourism and Gastronomy Studies, 7: 839-852.

Bayram, A. T., Ak, S. ve Erkol Bayram, G. (2018,). Üniversite Öğrencilerinin Tatil Tercihlerinde Sosyal Medya Kullanımı: Sinop Üniversitesi Örneği, VII. Ulusal III. Uluslararası Doğu Akdeniz Turizm Sempozyumu, 1089-1099.

Bayram, M., Keleş, Y. ve Bayram, Ü. (2017). Çevrimiçi Fotoğraflar Üzerinden Görsel Destinasyon İmajının İncelenmesi: Erzincan Doğa Sporları Örneği, Erzincan Üniversitesi Sosyal Bilimler Enstitüsü Dergisi, 4: 25-26.

Çevik, S. ve Sariipek, S. (2019). Fotoğraftan Yayılan Kavanta Kokusu: Sosyal Medyanın Destinasyon İmajına Etkisi, Proceeding of the 3th International Congress on Tourism, Economic and Business Sciences, 35-40.

Dina, R., and Sabou, G. (2012). Influence of Social Media in Choice of Touristic Destination, Cactus Tourism Journal, 3(2): 24-30.

Donaire, J. A., Camprubí, R., and Galí, N. (2014). Tourist Clusters from Flickr Travel Photography, Tourism Management Perspectives, 11: 26-33.

Dwivedi, M. (2009). Online Destination Image of India: A Consumer Based Perspective, International Journal of Contemporary Hospitality Management, 21(2): 226-232.

Eşitti, Ş. ve Işık, M. (2015). Sosyal Medyanın Yabancı Turistlerin Türkiye'yi Tatil Destinasyonu Olarak Tercih Etmelerine Etkisi, Karadeniz Uluslararası Bilimsel Dergi, 1(27): 11-33.

Font, X. (1997). Managing the Tourist Destination's Image, Journal of Vacation Marketing, 3(2): 123131.

Fotis, J., Buhalis, D., and Rossides, N., (2012). Social Media Use and Impact During the Holiday Travel Planning Process, (Editör) Fuchs, M, Ricci, F. and Cantoni, L., Information and Communication, Technologies in Tourism 2012 içinde (ss.13-24), Berlin/Heidelberg: Springer.

Giray, F. H., Kadakoğlu, B., Çetin, F. ve Abdoulaye Bamoi, A. G., (2019). Rural Tourism Marketing: Lavender Tourism in Turkey, Ciência Rural, 49(2): 1-15.

Granberg, L. (2019). The Role of Instagram in Choosing A Travel Destination, Bachelor Thesis, Luleå University of Technology, Luleå.

Gürbüz, S. ve Şahin, F. (2014). Sosyal Bilimlerde Araştırma Yöntemleri: Felsefe-Yöntem-Analiz, (4. Baskl) Ankara: Seçkin Yayıncılık. 
Hazar, M. (2011). Sosyal Medya Bağımlılığı-Bir Alan Çalışması, İletişim Kuram ve Araştırma Dergisi, 32: 151-176.

Ker, M. (1998). Profesyonel İmajın, İmaj Yönetimi Kapsamında Yeri ve Önemi, Pazarlama Dünyası Dergisi, 12(71): 25-28.

Kozak, M. (2018). Bilimsel Araştırma: Tasarım, Yazım ve Yayım Teknikleri, Ankara: Detay Yayıncılık.

Murugesan, S. (2007). Understanding Web 2.0, IT Professional, 9(4): 34-41.

Naik, U. and Shivalingaiah, D. (2008). Comparative Study of Web 1.0, Web 2.0 and Web 3.0, Proceeding of the 6th International CALIBER, 499-507.

Nath, K., Dhar, S. and Basishtha, S. (2014). Web 1.0 to Web 3.0 - Evolution of The Web and Its Various Challenges, 2014 International Conference on Reliability, Optimization and Information Technology (ICROIT), 86-89.

Ongun, U. ve Erbaş, E. (2020). Sosyal Medyanın Destinasyon Gelişimindeki Rolü: Lavanta Kokulu Kuyucak Köyü Örneği, Journal of Tourism and Gastronomy Studies, 8(4), 3129-3154.

Ongun, U., Gövdere, B. ve Durgun Kaygısız, A. (2015). Isparta İli Kırsal Alanlarında Yapılabilecek Kırsal Turizm Türlerinin Kırsal Kalkınmaya Etkisi, Uluslararası Sosyal ve Ekonomik Bilimler Dergisi, 5(1), 122-131.

Ongun, U., Gövdere, B. ve Kösekahyaoğlu, L. (2018). Kırsal Turizm Kapsamında Yerel Halkın Beklentileri: Isparta Kuyucak Lavanta Vadisi Örneği, Turizm ve Araştırma Dergisi, 7(2), 43-58.

Özaltaş Serçek, G. ve Serçek, S. (2017). X,Y ve Z Kuşaklarındaki Turistlerin Destinasyon İmaj Algılarının Karşılaştırılması, Seyahat ve Otel İşletmeciliği Dergisi, 14(1): 6-19.

Pike, S. (2002). Destination Image Analysis - A Reviewof 142 Papers from 1973 to 2000, Tourism Management, 23(5): 541-549.

Safko, L. (2010). The Social Media Bible: Tactics, Tools and Strategies for Business Success. New Jersey: John Wiley and Sons.

Sarı, Y. ve Kozak, M. (2005). Turizm Pazarlamasına İnternetin Etkisi: Destinasyon Web Siteleri İçin Bir Model Önerisi, Akdeniz Üniversitesi İ.I.B.F. Dergisi, 9: 248-271.

Terttunen, A. (2017). The Influence of Instagram on Consumers' Travel Planning and Destination Choice, Bachelor Thesis, Haaga-Helia University of Applied Sciences, Helsinki.

Tosun, C. and Jenkins, C. L. (1996) Regional Planning Approaches to Tourism Development: The Case of Turkey, Tourism Management, 17(7): 519-531.

Ünal, A. (2019). Instagram İçeriklerinin Yabancı Turistlerin Destinasyon Seçimleriyle İlgili Anlık Alg1 Değişimlerine Etkisinin Belirlenmesi, Turizm Akademik Dergisi, 7(1): 1-14.

Ünal, A. (2020). Sosyal Medyanın Destinasyon Marka Farkındalığı Kalitesi Üzerindeki Etkilerini Belirlemeye Yönelik Bir Araştırma, Journal of Hospitality and Tourism Issues, 2(1): 13-24.

Yıldırım, A. ve Şimşek, H. (2018). Sosyal Bilimlerde Nitel Araştırma Yöntemleri. (11. Baskı), Ankara: Seçkin Yayıncılık.

Yüksel, A. ve Yüksel, F. (2004). Turizmde Bilimsel Araştırma Yöntemleri, Ankara: Turhan Kitabevi. 